\title{
Appendices-Female genital mutilation/cutting: A review of laws and policies in Kenya and Nigeria
}

Samuel Kimani

Otibho Obianwu

Population Council

Follow this and additional works at: https://knowledgecommons.popcouncil.org/departments_sbsr-rh

Part of the Family, Life Course, and Society Commons, International Public Health Commons, Law and Gender Commons, and the Sociology of Culture Commons How does access to this work benefit you? Let us know!

\section{Recommended Citation}

Kimani, Samuel and Otibho Obianwu. 2020. "Appendices-Female genital mutilation/cutting: A review of laws and policies in Kenya and Nigeria," Evidence to End FGM/C: Research to Help Girls and Women Thrive. New York: Population Council. 


\section{Evidence to End FGM/C

ATTACHMENT: FEMALE GENITAL

MUTILATION/CUTTING: A REVIEW OF LAWS AND POLICIES IN KENYA AND NIGERIA

\section{REPORT APPENDICES}

SAMUEL KIMANI

AFRICA COORDINATING CENTRE FOR THE ABANDONMENT OF FEMALE GENITAL MUTILATION/CUTTING (ACCAF)

UNIVERSITY OF NAIROBI

OTIBHO OBIANWU

POPULATION COUNCIL

JUNE 2020

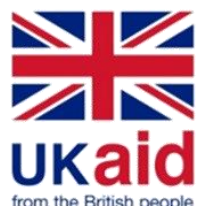




\section{Table of Contents}

Appendix 1 .

Components of Kenyan and Nigerian laws related to FGM/C prevention and management ......2

Table A1. Components of Kenyan laws related to FGM/C prevention and management.........2

Table A2. Components of Nigerian laws relevant to FGM/C prevention and management......6

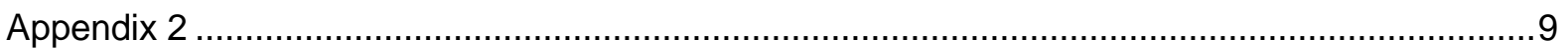

Components of Kenyan and Nigerian Policies, Plans of Action, Strategic Frameworks and Guidelines Related to FGM/C Prevention and Management

Table A3. Components relevant to health sector response to prevention and management of $\mathrm{FGM} / \mathrm{C}$ in Kenyan policies.

Table A4. Components relevant to health sector response to prevention and management of $\mathrm{FGM} / \mathrm{C}$ in Nigerian policies

Table A5. Components relevant to health sector response to prevention and management of $\mathrm{FGM} / \mathrm{C}$ in the Kenyan plans of actions

Table A6. Components relevant to health sector response to prevention and management of FGM/C in Nigerian plans of actions and strategic frameworks.

Table A7a. Components relevant to prevention and management of FGM/C in the Kenyan national school health guidelines

Table A7b. Components relevant to prevention and management of FGM/C in the Kenyan reference manual for health service providers.

Table A8. Components relevant to prevention and management of FGM/C in Nigerian Health sector guidelines. 


\section{Appendix 1}

\section{Components of Kenyan and Nigerian laws related to FGM/C prevention and management}

Table A1. Components of Kenyan laws related to FGM/C prevention and management

\begin{tabular}{|c|c|c|c|c|c|}
\hline & & $\begin{array}{l}\text { Prohibition of } \\
\text { FGM Act } 2011\end{array}$ & $\begin{array}{l}\text { The Children's Act } \\
2001\end{array}$ & The Penal Code Cap 63 & $\begin{array}{l}\text { The Protection } \\
\text { against Domestic } \\
\text { Violence Act } 2015\end{array}$ \\
\hline \multicolumn{6}{|c|}{ Components related to FGM/C prevention } \\
\hline 1 & $\begin{array}{l}\text { Framing of the law depicts its role in addressing } \\
\text { FGM/C from the onset. }\end{array}$ & $\begin{array}{l}\text { The Act prohibit } \\
\text { FGM to prevent } \\
\text { violation of physical } \\
\text { and mental integrity } \\
\text { of a person. }\end{array}$ & $\begin{array}{l}\text { The Act provide for } \\
\text { parental care and } \\
\text { protection of children as } \\
\text { stipulated in the } \\
\text { Convention on the } \\
\text { Rights of the Child and } \\
\text { the African Charter on } \\
\text { the Rights and Welfare } \\
\text { of the Child }\end{array}$ & $\begin{array}{l}\text { The Act outlaws the } \\
\text { deliberate infliction of } \\
\text { 'grievous harm', which } \\
\text { includes 'any permanent } \\
\text { or serious injury to any } \\
\text { external or internal } \\
\text { organ, membrane or } \\
\text { sense'. }\end{array}$ & $\begin{array}{l}\text { The Act provide for } \\
\text { protection and relief } \\
\text { of domestic violence } \\
\text { of which FGM/C has } \\
\text { been defined as so. }\end{array}$ \\
\hline 2 & Criminalises performance of $\mathrm{FGM} / \mathrm{C}$ & Yes & Yes & Yes & Yes \\
\hline 3 & $\begin{array}{l}\text { Criminalises performance of FGM/C on a consenting } \\
\text { adult }\end{array}$ & Yes & Yes & No & No \\
\hline 4 & Criminalises performance of FGM/C on children & Yes & Yes & Yes & Yes \\
\hline 5 & $\begin{array}{l}\text { Criminalises any acts related to FGM/C e.g. aiding, } \\
\text { abetting, counselling or procuring a person to perform } \\
\text { FGM/C }\end{array}$ & Yes & Yes & No & Yes \\
\hline 6 & Criminalises medicalisation of FGM/C & Yes & Yes & Yes & Yes \\
\hline 7 & $\begin{array}{l}\text { Criminalises procuring a person to perform FGM/C in } \\
\text { another country or arranging for another person to be } \\
\text { brought into Kenya for FGM/C (cross border FGM/C) }\end{array}$ & Yes & No & No & No \\
\hline 8 & $\begin{array}{l}\text { Criminalises the practice of FGM/C outside Kenya by } \\
\text { Kenyan citizens or permanent residents }\end{array}$ & Yes & No & No & No \\
\hline 9 & $\begin{array}{l}\text { Criminalises allowing use of premises to perform } \\
\text { FGM/C }\end{array}$ & Yes & No & No & No \\
\hline 10 & $\begin{array}{l}\text { Criminalises possession of tools or equipment for a } \\
\text { purpose of performance of } F G M / C\end{array}$ & Yes & No & No & No \\
\hline
\end{tabular}




\begin{tabular}{|c|c|c|c|c|c|}
\hline & & $\begin{array}{l}\text { Prohibition of } \\
\text { FGM Act } 2011\end{array}$ & $\begin{array}{l}\text { The Children's Act } \\
2001\end{array}$ & The Penal Code Cap 63 & $\begin{array}{l}\text { The Protection } \\
\text { against Domestic } \\
\text { Violence Act } 2015\end{array}$ \\
\hline 11 & $\begin{array}{l}\text { Criminalises failure to report performance of FGM/C to } \\
\text { a law enforcement officer }\end{array}$ & Yes & No & No & No \\
\hline 12 & $\begin{array}{l}\text { Provides for law enforcement officer to enter any } \\
\text { premises for the purposes of ascertaining whether } \\
\text { there is or has been used to perform FGM/C without } \\
\text { warrant }\end{array}$ & Yes & No & No & Yes \\
\hline \multicolumn{6}{|c|}{ Stipulates penalties related to performance of FGM/C } \\
\hline 13 & $\begin{array}{l}\text { Prescribes punishments for offences/acts of } \\
\text { commission or omission under the act }\end{array}$ & Yes & Yes & Yes & Yes \\
\hline 14 & Prescribed penalties performance of FGM/C & $\begin{array}{l}\text { Offences are } \\
\text { punishable with } \\
\text { imprisonment for a } \\
\text { term of not less } \\
\text { than three years, or } \\
\text { to a fine of not less } \\
\text { than Kenya } \\
\text { Shillings } 200,000 \text {, } \\
\text { or both }\end{array}$ & $\begin{array}{l}\text { A fine not exceeding } \\
\text { Kshs } 200,000 \text {, or to } \\
\text { imprisonment for a term } \\
\text { not exceeding five } \\
\text { years, or to both: }\end{array}$ & Yes & $\begin{array}{l}\text { In the case of an } \\
\text { individual, to a fine } \\
\text { not } \\
\text { Exceeding Kshs } \\
50,000 \text { or to } \\
\text { imprisonment for a } \\
\text { term of three years, } \\
\text { or to both } \\
\text { In case of a } \\
\text { corporate body, to a } \\
\text { fine not } \\
\text { exceeding Kshs } \\
500,000 \text {. }\end{array}$ \\
\hline 15 & $\begin{array}{l}\text { Prescribes penalty for any FGM/C-related grievous } \\
\text { harm to another as is guilty of a felony and is liable to } \\
\text { imprisonment for life. }\end{array}$ & No & Yes & Yes & No \\
\hline 16 & $\begin{array}{l}\text { Prescribes punishment if in the process of performing } \\
\text { FGM/C a person causes the death of another }\end{array}$ & Yes & No & No & No \\
\hline 17 & $\begin{array}{l}\text { Prescribes punishments/fines related to use of } \\
\text { derogatory words on non-cut women or men who } \\
\text { marry or otherwise support a woman who has not } \\
\text { undergone FGM/C }\end{array}$ & Yes & No & No & No \\
\hline 18 & $\begin{array}{l}\text { Provide for establishment of the Children's Council that } \\
\text { ensures the full implementation of Kenya's } \\
\text { international and regional obligations relating to }\end{array}$ & No & Yes & No & No \\
\hline
\end{tabular}




\begin{tabular}{|c|c|c|c|c|c|}
\hline & & $\begin{array}{l}\text { Prohibition of } \\
\text { FGM Act } 2011\end{array}$ & $\begin{array}{l}\text { The Children's Act } \\
2001\end{array}$ & The Penal Code Cap 63 & $\begin{array}{l}\text { The Protection } \\
\text { against Domestic } \\
\text { Violence Act } 2015\end{array}$ \\
\hline & $\begin{array}{l}\text { children and facilitates the formulation of appropriate } \\
\text { reports under such obligations }\end{array}$ & & & & \\
\hline 19 & $\begin{array}{l}\text { Provide for establishment of Children's Council that } \\
\text { formulates strategies for the creation of public } \\
\text { awareness in all matters touching on the rights and } \\
\text { welfare of children }\end{array}$ & No & Yes & No & No \\
\hline 20 & $\begin{array}{l}\text { Provides for training police officers to deal with family } \\
\text { related matters or domestic violence }\end{array}$ & No & No & No & Yes \\
\hline 21 & $\begin{array}{l}\text { Facilitates the reporting process so that complainants } \\
\text { may report to the police without fear or otherwise }\end{array}$ & No & No & No & Yes \\
\hline 22 & $\begin{array}{l}\text { Provides for expedient and efficient processing of } \\
\text { complaints }\end{array}$ & No & No & No & Yes \\
\hline 23 & $\begin{array}{l}\text { Provides for witness protection against any person } \\
\text { who attacks, intimidates or harms a } \\
\text { person who reports domestic violence commits an } \\
\text { offence. }\end{array}$ & No & No & Yes & Yes \\
\hline 24 & $\begin{array}{l}\text { Provides for witness anonymity in any proceeding } \\
\text { under this Act }\end{array}$ & No & No & Yes & Yes \\
\hline 25 & $\begin{array}{l}\text { Provide for compensation of victim of domestic } \\
\text { violence who suffers personal injuries or damage to } \\
\text { property or financial loss as the court deems just and } \\
\text { reasonable. }\end{array}$ & No & No & No & Yes \\
\hline \multicolumn{6}{|c|}{ Components related to management of FGM/C-related complications } \\
\hline 26 & $\begin{array}{l}\text { Prescribes the provision of support services, protection } \\
\text { and care to victims of } F G M / C\end{array}$ & Yes & Yes & No & Yes \\
\hline 27 & $\begin{array}{l}\text { Prescribes public education and sensitising Kenyans } \\
\text { on the dangers and adverse effects of } F G M / C\end{array}$ & Yes & No & No & No \\
\hline 28 & $\begin{array}{l}\text { Provided for protection of a child against domestic } \\
\text { violence }\end{array}$ & No & Yes & No & Yes \\
\hline 29 & $\begin{array}{l}\text { Provides for recording and preservation of any } \\
\text { information } \\
\text { regarding the condition of the child following FGM/C by } \\
\text { the health institution and medical practitioner }\end{array}$ & No & Yes & No & No \\
\hline
\end{tabular}




\begin{tabular}{|c|c|c|c|c|c|}
\hline & & $\begin{array}{l}\text { Prohibition of } \\
\text { FGM Act } 2011\end{array}$ & $\begin{array}{l}\text { The Children's Act } \\
2001\end{array}$ & The Penal Code Cap 63 & $\begin{array}{l}\text { The Protection } \\
\text { against Domestic } \\
\text { Violence Act } 2015\end{array}$ \\
\hline 30 & $\begin{array}{l}\text { Provides for defrayment of expenses incurred in } \\
\text { connection with the medical treatment or hospital } \\
\text { accommodation of a child out of public funds. }\end{array}$ & No & Yes & No & No \\
\hline 31 & $\begin{array}{l}\text { Provides for intervention on behalf of any child who } \\
\text { needs care and protection and is in danger of imminent } \\
\text { injury or harm, where possible by securing the removal } \\
\text { of such child to a place of safety }\end{array}$ & No & Yes & No & Yes \\
\hline
\end{tabular}


Table A2. Components of Nigerian laws relevant to FGM/C prevention and management.

\begin{tabular}{|c|c|c|}
\hline $\begin{array}{l}\text { Components of Laws Relevant } \\
\text { to FGM/C prevention and } \\
\text { management }\end{array}$ & Violence Against Persons (Prohibition) Act 2015 & Imo State FGM (Prohibition) Law 2017 \\
\hline Aim of the law & $\begin{array}{l}\text { To eliminate violence in private and public life, } \\
\text { prohibit all forms of violence against persons, } \\
\text { provide maximum protection and effective remedies } \\
\text { for victims and punishment of offenders, and other } \\
\text { related matters. }\end{array}$ & $\begin{array}{l}\text { To prohibit the act of FGM/C in Imo State and for other related } \\
\text { matters }\end{array}$ \\
\hline Definition of FGM/C & $\begin{array}{l}\text { Refers to FGM/C as "circumcision" and "genital } \\
\text { mutilation" and defines "circumcision of a girl or } \\
\text { women" as "cutting off all or part of the external sex } \\
\text { organs of a girl or woman other than on medical } \\
\text { ground." }\end{array}$ & $\begin{array}{l}\text { Refers to FGM/C as "Female Genital Mutilation" which it defines } \\
\text { as including: } \\
\text { - Clitoridectomy } \\
\text { - } \quad \text { Incision } \\
\text { - Introcision, including "gishiri" cuts; } \\
\text { - "Angurya cut," that is scraping or cutting of the vagina; } \\
\text { - Pricking, piercing or incising of the clitoris or labia; } \\
\text { - Stretching of the clitoris or labia; } \\
\text { - } \text { vauterisation, that is, searing of the clitoris, labia, and } \\
\text { - insensitive; } \\
\text { - Introduction of corrosive substances and herbs in the } \\
\text { vagina, in order to desensitise it; and } \\
\text { Other forms of female genital mutilation. }\end{array}$ \\
\hline Provision criminalising FGM/C & $\begin{array}{l}\text { The circumcision or genital mutilation of the girl child } \\
\text { or woman is prohibited. }\end{array}$ & $\begin{array}{l}\text { Female Genital Mutilation (FGM) is prohibited, any custom or } \\
\text { tradition notwithstanding. }\end{array}$ \\
\hline $\begin{array}{l}\text { Provision criminalising } \\
\text { performance of FGM/C and } \\
\text { penalty }\end{array}$ & $\begin{array}{l}\text { A person who performs female circumcision or } \\
\text { genital mutilation or engages another to carry out } \\
\text { such circumcision or mutilation commits an offence } \\
\text { and is liable on conviction to a term of imprisonment } \\
\text { not exceeding } 4 \text { years or to a fine not exceeding } \\
\text { N200,000 }\left(\sim 554 \text { as of June } 25^{\text {th }}, 2019\right) \text { or both. }\end{array}$ & $\begin{array}{l}\text { Any person who knowingly separates or surgically alters the } \\
\text { normal healthy functioning genital tissue/organ of a female, } \\
\text { circumcises, pricks, pierces, cuts or infibulates the whole or any } \\
\text { part of the labia majora or minora of a female or performs any } \\
\text { other form of Female Genital Mutilation as described in Section } 2 \\
\text { of this Law is guilty of an offence. Liable on conviction to } \\
\text { imprisonment for } 14 \text { years or a fine of N250,000 }(\sim 693)\end{array}$ \\
\hline $\begin{array}{l}\text { Provision for attempting to practice } \\
\text { FGM/C and penalty }\end{array}$ & $\begin{array}{l}\text { A person who attempts to perform female } \\
\text { circumcision or genital mutilation or to engage } \\
\text { another to carry out such circumcision or mutilation } \\
\text { commits an offence and is liable on conviction to a }\end{array}$ & None \\
\hline
\end{tabular}




\begin{tabular}{|c|c|c|}
\hline $\begin{array}{l}\text { Components of Laws Relevant } \\
\text { to FGM/C prevention and } \\
\text { manaqement }\end{array}$ & Violence Against Persons (Prohibition) Act 2015 & Imo State FGM (Prohibition) Law 2017 \\
\hline & $\begin{array}{l}\text { term of imprisonment not exceeding } 2 \text { years or to a } \\
\text { fine not exceeding } N 100,000(\sim 277) \text { or both. }\end{array}$ & \\
\hline $\begin{array}{l}\text { Provision for aiding, abetting, } \\
\text { and/or inciting FGM/C and penalty }\end{array}$ & $\begin{array}{l}\text { A person who incites, aids, abets, or counsels } \\
\text { another person to perform female circumcision or } \\
\text { genital mutilation or to engage another to carry out } \\
\text { such circumcision or mutilation commits an offence } \\
\text { and is liable on conviction to a term of imprisonment } \\
\text { not exceeding } 2 \text { years or to a fine not exceeding } \\
\mathrm{N} 100,000(\sim 277) \text { or both. }\end{array}$ & $\begin{array}{l}\text { Any person who aids and abets the performance of Female } \\
\text { Genital Mutilation is guilty to an offence and shall be liable on } \\
\text { conviction, to imprisonment for seven }(7) \text { years or to a fine of } \\
N 150,000(\sim 415)\end{array}$ \\
\hline $\begin{array}{l}\text { Provision forbidding FGM/C in } \\
\text { consenting adults and the penalty }\end{array}$ & Implied & $\begin{array}{l}\text { Any adult female who willingly submits herself for the performance } \\
\text { of Female Genital Mutilation is guilty of the offence of Female } \\
\text { Genital Mutilation and liable on conviction to imprisonment for } 14 \\
\text { years or a fine of N250,000 ( } \$ 692)\end{array}$ \\
\hline $\begin{array}{l}\text { Provision prohibiting the use of } \\
\text { consent as a defence }\end{array}$ & None & $\begin{array}{l}\text { It shall not be a defence to any offence committed under this Law } \\
\text { that the victim consented to have Female Genital Mutilation } \\
\text { performed on her or that the victim's parents or legal guardians } \\
\text { consented to the practice }\end{array}$ \\
\hline $\begin{array}{l}\text { Provision criminalising assault, } \\
\text { disability, discrimination due to } \\
\text { refusal to undergo FGM/C and } \\
\text { penalty }\end{array}$ & None & $\begin{array}{l}\text { No person shall assault or cause another to suffer a disability or } \\
\text { discrimination on the ground that that such a person refused to } \\
\text { undergo the act of Female Genital Mutilation. Liable on conviction } \\
\text { to } 3 \text { years imprisonment and/or a fine of } N 100,000(\sim \$ 277) \text {. }\end{array}$ \\
\hline $\begin{array}{l}\text { Provision for out of jurisdiction } \\
\text { practice of FGM/C and penalty } \\
\text { (extraterritorial clause) }\end{array}$ & None & $\begin{array}{l}\text { Any person who does anything for the purpose of removing from } \\
\text { the State, a person who is ordinarily resident in the State and } \\
\text { performs the act of Female Genital Mutilation on such person is } \\
\text { guilty of the offence of Female Genital Mutilation. Liable on } \\
\text { conviction to imprisonment for } 14 \text { years or a fine of N250,000 } \\
(\sim 692)\end{array}$ \\
\hline $\begin{array}{l}\text { Provision forbidding medicalisation } \\
\text { of FGM/C and penalty }\end{array}$ & Implied & Implied \\
\hline $\begin{array}{l}\text { Provision mandating reporting of } \\
\text { the offence and penalty }\end{array}$ & None & None \\
\hline $\begin{array}{l}\text { Provision mandating a duty to } \\
\text { avert and penalty }\end{array}$ & None & None \\
\hline $\begin{array}{l}\text { Institution mandated to administer } \\
\text { provisions of the law }\end{array}$ & $\begin{array}{l}\text { National Agency for the Prohibition of Trafficking in } \\
\text { Persons and other related matters (NAPTIP) in }\end{array}$ & $\begin{array}{l}\text { Not stated but specific roles are given for the Commissioner in } \\
\text { charge of Health matters in collaboration with the Ministries }\end{array}$ \\
\hline
\end{tabular}




\begin{tabular}{|c|c|c|}
\hline Components of Laws Relevant & Violence Against Persons (Prohibition) Act 2015 & Imo State FGM (Prohibition) Law 2017 \\
\hline & $\begin{array}{l}\text { collaboration with relevant stakeholders including } \\
\text { faith-based organisations }\end{array}$ & $\begin{array}{l}\text { responsible for Women Affairs/Social Development and } \\
\text { Information, international donor agencies, and other non- } \\
\text { governmental agencies. The Ministry in charge of Health matters } \\
\text { in the state is also given specific responsibilities. All } \\
\text { responsibilities are detailed in the row below. }\end{array}$ \\
\hline $\begin{array}{l}\text { Provisions relevant to the } \\
\text { management of women/girls who } \\
\text { have undergone FGM/C }\end{array}$ & $\begin{array}{l}\text { - Service providers, including health personnel, } \\
\text { can complete the violence incidence report with } \\
\text { the consent of the victim and forward it to the } \\
\text { Magistrates and the Protection Officer having } \\
\text { jurisdiction in the area where FGM/C occurred } \\
\text { Any victim of violence, including FGM/C, has } \\
\text { the right to information about health services } \\
\text { and is entitled to comprehensive medical and } \\
\text { psychological assistance through governmental } \\
\text { and non-governmental agencies that provide } \\
\text { such assistance. } \\
\text { Appointed Protection Officers are also required } \\
\text { to ensure that victims have easy access to } \\
\text { transportation to the nearest hospital or medical } \\
\text { facility for treatment if victims so require. } \\
\text { The appropriate Government Ministry (in this } \\
\text { case the Ministry of Health) shall keep a register } \\
\text { of all accredited service providers and circulate } \\
\text { this information to all police stations, protection } \\
\text { officers and the courts. The Ministry is also } \\
\text { required to develop guidelines for the operation } \\
\text { of the accredited service providers. }\end{array}$ & $\begin{array}{l}\text { The Commissioner in charge of Health matters in the state in } \\
\text { collaboration with: } \\
\text { - Ministries for Women Affairs/Social Development and } \\
\text { Information, international donor agencies, and other NGOs } \\
\text { shall initiate and carry out educative and preventive outreach } \\
\text { programmes in communities that traditionally practice FGM/C } \\
\text { for the purpose of informing members of those communities, } \\
\text { the health risks and complications associated with the } \\
\text { performance of FGM/C as well as bringing the provisions of } \\
\text { the law to their notice } \\
\text { The Ministry in charge of Health matters in the state shall: } \\
\text { compile data of women/girls that have undergone FGM/C in } \\
\text { the state especially those under the age of eighteen years } \\
\text { ensure that the risks and complications associated with the } \\
\text { practice of FGM/C are incorporated into the curricula of the } \\
\text { state-owned Medical Schools, Schools of Nursing and other } \\
\text { Schools offering health related courses in the state. }\end{array}$ \\
\hline
\end{tabular}




\section{Appendix 2}

\section{Components of Kenyan and Nigerian Policies, Plans of Action, Strategic Frameworks and Guidelines Related to FGM/C Prevention and Management}

Table A3. Components relevant to health sector response to prevention and management of FGM/C in Kenyan policies

\begin{tabular}{|c|c|c|}
\hline $\begin{array}{l}\text { Components related to prevention } \\
\text { and management of FGM/C }\end{array}$ & $\begin{array}{l}\text { National Adolescent Sexual and Reproductive Health } \\
\text { (ASRH) Policy } 2015\end{array}$ & National School Health Policy 2009 (Revised 2018) \\
\hline $\begin{array}{l}\text { Relevance of the policy in } \\
\text { responding to FGM/C prevention } \\
\text { and management is captured under } \\
\text { child's rights and responsibility } \\
\text { thematic area }\end{array}$ & & $\begin{array}{l}\text { The policy highlights the components of a comprehensive } \\
\text { school health programme to include child's rights and } \\
\text { responsibilities }\end{array}$ \\
\hline $\begin{array}{l}\text { Situation analysis provides solid } \\
\text { ground for the policy/review- aligned } \\
\text { to the Constitution of Kenya } 2010 \\
\text { and the devolved governance } \\
\text { structures in Health and Education }\end{array}$ & $\begin{array}{l}\text { The review of the policy was prompted by among others: } \\
\text { emerging issues which adolescents are vulnerable to such } \\
\text { as FGM/C. These harmful traditional practices impact } \\
\text { negatively on adolescent health and future well-being. }\end{array}$ & $\begin{array}{l}\text { The } 2009 \text { School Health Policy implementation and the } \\
\text { Constitution of Kenya } 2010 \text { realigned the education and } \\
\text { health structures. Some functions were devolved, while in } \\
\text { 2013, the Basic Education Act } 2013 \text { legal framework was } \\
\text { developed. }\end{array}$ \\
\hline $\begin{array}{l}\text { Definition and classification of } \\
\text { FGM/C is consistent with WHO } \\
\text { criteria }\end{array}$ & $\begin{array}{l}\text { FGM/C comprises all procedures involving partial or total } \\
\text { removal of the female genitalia or any other injury to the } \\
\text { female genital organs or any harmful procedure to the } \\
\text { female genitalia, for nonmedical reasons. Classifies FGM/C } \\
\text { into: clitoridectomy, excision and infibulation. }\end{array}$ & $\begin{array}{l}\text { The policy only reports on harmful practices including } \\
\text { FGM/C without the definition and its classification. }\end{array}$ \\
\hline $\begin{array}{l}\text { The preamble highlights the legal } \\
\text { frameworks and context in which } \\
\text { FGM/C is addressed }\end{array}$ & $\begin{array}{l}\text { The policy acknowledges adolescents face FGM/C as a } \\
\text { challenge that is addressed through Kenya being a } \\
\text { signatory to several international and regional human rights } \\
\text { treaties and declarations. It also recognises that nationally, } \\
\text { FGM/C issues are addressed within various legislative and } \\
\text { policy frameworks including the Constitution of Kenya } \\
\text { (2010), Children's Act (2001), Prohibition of FGM Act } \\
\text { (2011), and National School Health Policy } 2009 \text {. }\end{array}$ & $\begin{array}{l}\text { The policy highlights the implementation of the UN } \\
\text { Convention on the Rights of the Child and the African } \\
\text { Charter on the Rights and Welfare of the Child that } \\
\text { protects children. Nationally, it highlights the Children Act } \\
2001 \text { that safeguard and protect children. } \\
\text { Regarding FGM/C it puts measures to discourage } \\
\text { negative cultural beliefs and practices that support } \\
\text { FGM/C. }\end{array}$ \\
\hline $\begin{array}{l}\text { Contains guiding principles relevant } \\
\text { to addressing FGM/C }\end{array}$ & $\begin{array}{l}\text { Respect for human rights and fundamental freedoms } \\
\text { including the right to life, human dignity, equality and } \\
\text { freedom from discrimination based on gender, sex, age, } \\
\text { disability, health status, geographical location or social, } \\
\text { cultural and religious beliefs and practices. }\end{array}$ & $\begin{array}{l}\text { Under safety in learning institution, the policy provides } \\
\text { that all learning institutions shall provide a safe } \\
\text { psychosocial environment. } \\
\text { Emphasises there shall be no tolerance for sexual } \\
\text { harassment, abuse and other forms of juvenile } \\
\text { exploitation. }\end{array}$ \\
\hline
\end{tabular}




\begin{tabular}{|c|c|c|}
\hline $\begin{array}{l}\text { Components related to prevention } \\
\text { and management of FGM/C }\end{array}$ & $\begin{array}{l}\text { National Adolescent Sexual and Reproductive Health } \\
\text { (ASRH) Policy } 2015\end{array}$ & National School Health Policy 2009 (Revised 2018) \\
\hline $\begin{array}{l}\text { Provides for prevention and } \\
\text { management of FGM/C }\end{array}$ & $\begin{array}{l}\text { Responsiveness to varying sexual reproductive health } \\
\text { needs of adolescents in provision of care. }\end{array}$ & $\begin{array}{l}\text { The policy highlights the comprehensive school health } \\
\text { programme, enabling address to health and education } \\
\text { needs of learners, teachers and their families. } \\
\text { Notably the programme shall provide for good health } \\
\text { education and health services to promote the overall } \\
\text { health of children including provision of mental, } \\
\text { psychological health of child by providing a positive, safe } \\
\text { physical and psychological environment. }\end{array}$ \\
\hline $\begin{array}{l}\text { Captures FGM/C as an important } \\
\text { issue affecting health }\end{array}$ & $\begin{array}{l}\text { FGM/C is classified as a harmful practice that has a direct } \\
\text { impact on reproductive health activities and status of } \\
\text { adolescents and young people. } \\
\text { FGM/C is associated with immediate, long term social, } \\
\text { physical, psychological and health consequences. } \\
\text { In addition, girls who undergo FGM/C as a rite of passage } \\
\text { are likely to drop out of school, experience child marriage } \\
\text { and early child-bearing. }\end{array}$ & $\begin{array}{l}\text { The policy stipulates child rights, child protection and } \\
\text { responsibilities as one of the components of the } \\
\text { comprehensive school health programme. } \\
\text { The revised school health policy addresses FGM/C under } \\
\text { the gender, growth and development thematic area. } \\
\text { Notably highlights FGM as a form of GBV, it is still } \\
\text { prevalent in the country and this has far reaching } \\
\text { implications on the education, health and general well- } \\
\text { being of learners. } \\
\text { FGM/C is also addressed under child rights and } \\
\text { responsibilities thematic area. } \\
\text { Emphasis is given on child rights as articulated in the } \\
\text { United Nations Convention on the Rights of the Child } \\
\text { (UNCRC, 1989). }\end{array}$ \\
\hline $\begin{array}{l}\text { Policy goals, objectives and } \\
\text { strategies addresses FGM/C } \\
\text { prevention and management }\end{array}$ & $\begin{array}{l}\text { FGM/C is addressed in the following objectives: } \\
\text { Promote adolescent sexual reproductive health and rights; } \\
\text { Reduce harmful traditional practices and sexual gender } \\
\text { based violence incidence amongst adolescents to improve } \\
\text { response }\end{array}$ & $\begin{array}{l}\text { FGM/C is addressed in the following objectives: Promote } \\
\text { gender related issues in schools; } \\
\text { Enhance child rights and protection in schools. } \\
\text { Inform the learners, parents and the community on the } \\
\text { rights and responsibilities of the child } \\
\text { Safeguard them from child rights abuse and ensure they } \\
\text { take up their responsibilities. } \\
\text { Safeguard learners from all forms of gender based } \\
\text { violence and harmful cultural practices as well as help } \\
\text { them transcend gender dynamics that may affect their } \\
\text { education, health and wellbeing }\end{array}$ \\
\hline Policy statement & & $\begin{array}{l}\text { Ministry of Education in collaboration with ministry of } \\
\text { Health and other stakeholders shall address gender }\end{array}$ \\
\hline
\end{tabular}




\begin{tabular}{|c|c|c|}
\hline $\begin{array}{l}\text { Components related to prevention } \\
\text { and management of } \mathrm{FGM} / \mathrm{C}\end{array}$ & $\begin{array}{l}\text { National Adolescent Sexual and Reproductive Health } \\
\text { (ASRH) Policy } 2015\end{array}$ & National School Health Policy 2009 (Revised 2018) \\
\hline & & $\begin{array}{l}\text { related issues which affect the education, health and } \\
\text { wellbeing of learners. } \\
\text { Ministry of Education in collaboration with other } \\
\text { stakeholders shall promote, safeguard and protect the } \\
\text { rights of the learners and ensure that they carry out their } \\
\text { responsibilities. }\end{array}$ \\
\hline $\begin{array}{l}\text { Policy related strategies for } \\
\text { addressing FGM included }\end{array}$ & $\begin{array}{l}\text { Strengthen capacities of institutions, communities, families } \\
\text { and individuals to prevent and respond to harmful } \\
\text { traditional practices to adolescents; } \\
\text { Encourage male involvement in prevention of harmful } \\
\text { traditional practices; } \\
\text { Ensure monitoring and evaluation of interventions that are } \\
\text { geared towards prevention, response and mitigation of } \\
\text { traditional practices; } \\
\text { Support management of health consequences of harmful } \\
\text { traditional practices; } \\
\text { Support implementation of appropriate policies and } \\
\text { programs, as well as enforcement of legislation to reduce } \\
\text { prevalence of harmful traditional practices; } \\
\text { Support sensitisation of communities on existing legislation } \\
\text { and policies that protect adolescents from harmful } \\
\text { traditional practices; } \\
\text { Support programs and research on harmful traditional } \\
\text { practices and promote appropriate evidence-based } \\
\text { interventions; and } \\
\text { Support sensitisation of reintegration to school of } \\
\text { adolescents in early marriage and FGM situations. }\end{array}$ & $\begin{array}{l}\text { Enhance the safeguard against gender based violence } \\
\text { amongst learners. } \\
\text { Strengthen safeguard and protect the learners from } \\
\text { harmful cultural practices. } \\
\text { Provide and promote a conducive environment for the } \\
\text { learners to enjoy survival and development rights. } \\
\text { Provide and promote conducive environment for the } \\
\text { enjoyment of the protection rights by the learner. }\end{array}$ \\
\hline $\begin{array}{l}\text { Priority areas and actions related to } \\
\text { FGM/C addressed by the policy to } \\
\text { achieve the objectives }\end{array}$ & $\begin{array}{l}\text { Strengthen capacities of institutions, communities, families } \\
\text { and individuals to prevent and respond to harmful } \\
\text { traditional practices to adolescents; } \\
\text { Encourage male involvement in prevention of harmful } \\
\text { traditional practices; } \\
\text { Ensure M\&E of interventions that are geared towards } \\
\text { prevention, response and mitigation of traditional practices; } \\
\text { Support management of health consequences of harmful } \\
\text { traditional practices; }\end{array}$ & $\begin{array}{l}\text { The policy identifies strategies for effective } \\
\text { implementation of skills-based health curriculum } \\
\text { including; gender issues and how they can affect health } \\
\text { e.g. FGM/C are addressed. Specifically, the policy } \\
\text { stipulates that schools and communities shall be: } \\
\text { Sensitised and supported communities to do away with } \\
\text { FGM/C. } \\
\text { Enlighten the youth on FGM/C by carrying out the } \\
\text { sensitisation on the existence of FGM/C } \\
\text { Information to students on the existence of FGM/C, }\end{array}$ \\
\hline
\end{tabular}




\begin{tabular}{|c|c|c|}
\hline $\begin{array}{l}\text { Components related to prevention } \\
\text { and management of FGM/C }\end{array}$ & $\begin{array}{l}\text { National Adolescent Sexual and Reproductive Health } \\
\text { (ASRH) Policy } 2015\end{array}$ & National School Health Policy 2009 (Revised 2018) \\
\hline & $\begin{array}{l}\text { Support implementation of appropriate policies and } \\
\text { programmes, as well as enforcement of legislation to } \\
\text { reduce prevalence of harmful traditional practices; Support } \\
\text { sensitisation of communities on existing legislation and } \\
\text { policies that protect adolescents from harmful traditional } \\
\text { practices; } \\
\text { Support programmes and research on harmful traditional } \\
\text { practices and promote appropriate evidence-based } \\
\text { interventions; and } \\
\text { Support sensitisation of reintegration to school of } \\
\text { adolescents in early marriage and FGM situations; } \\
\text { Strengthen provision of medical, legal and psychosocial } \\
\text { support for adolescent survivors of SGBV; } \\
\text { Enhance capacity of law enforcers and health service } \\
\text { providers on prevention, response and mitigation of SGBV. }\end{array}$ & $\begin{array}{l}\text { Raise awareness to students to understand } \\
\text { consequences of FGM/C, } \\
\text { Educate the pupils, teachers, parents and communities } \\
\text { on FGM/C and control measures, } \\
\text { Students exposed to FGM/C shall be counselled and } \\
\text { rehabilitated }\end{array}$ \\
\hline $\begin{array}{l}\text { Implementation framework of the } \\
\text { policy is well elaborated }\end{array}$ & $\begin{array}{l}\text { The following structures are identified for implementing } \\
\text { relevant FGM/C related components of the policy: county } \\
\text { health management teams, county hospital management } \\
\text { teams, sub-county health management teams, primary } \\
\text { care facility management teams and community units. } \\
\text { Additionally, collaboration and partnerships shall be } \\
\text { realised through Joint Interagency Coordinating } \\
\text { Committee; Health Sector Coordinating Committees; } \\
\text { County Health Stakeholders' Forum; Sub-County Health } \\
\text { Stakeholders' Forum and Community Health Committees. } \\
\text { The Policy encourages formation of technical working } \\
\text { groups at the county and sub-county levels. }\end{array}$ & $\begin{array}{l}\text { Relevant programme activities shall be implemented } \\
\text { within the existing relevant laws of Kenya such as, the } \\
\text { Children's Act } 2001 \text {. The school health programme is an } \\
\text { inter-sectoral initiative in which ministries, stakeholders } \\
\text { and agencies will collaborate in planning, } \\
\text { implementation, M\&E of activities. Overall, coordination } \\
\text { of all aspects of implementation of all health-related } \\
\text { activities within school will be the responsibility of Ministry } \\
\text { of Education and its stakeholders in collaboration with } \\
\text { Ministry of Public Health and Sanitation (currently known } \\
\text { as the Ministry of Health) to provide preventive, } \\
\text { promotive, curative and rehabilitative services. } \\
\text { Revised SHP provides for compulsory adoption of the } \\
\text { school health policy in all schools within the provisions of } \\
\text { the Education and Health statutes. }\end{array}$ \\
\hline $\begin{array}{l}\text { Provides an elaborate } \\
\text { implementation guideline }\end{array}$ & $\begin{array}{l}\text { The policy provides for the implementation in a devolved } \\
\text { health system across the following tiers/levels: Community } \\
\text { Health Services, } \\
\text { Primary Care Services, } \\
\text { County Referral Services, and } \\
\text { National Referral Services. }\end{array}$ & $\begin{array}{l}\text { The policy provides for implementation through an } \\
\text { interagency coordinating committee between the Ministry } \\
\text { of Education and the Ministry of Health. } \\
\text { This structure of the committee shall be cascaded } \\
\text { through the administrative hierarchy namely national, } \\
\text { provincial, district, division, location and the community } \\
\text { (school). }\end{array}$ \\
\hline
\end{tabular}




\begin{tabular}{|c|c|c|}
\hline $\begin{array}{l}\text { Components related to prevention } \\
\text { and management of } \mathrm{FGM} / \mathrm{C}\end{array}$ & $\begin{array}{l}\text { National Adolescent Sexual and Reproductive Health } \\
\text { (ASRH) Policy } 2015\end{array}$ & National School Health Policy 2009 (Revised 2018) \\
\hline & $\begin{array}{l}\text { Those facilities operated by NGOs, faith-based } \\
\text { organisations and private for-profit sector shall follow the } \\
\text { same classification depending on their level of resources } \\
\text { and capacity. } \\
\text { The county governments shall be responsible for } \\
\text { Community Health, Primary Care, and County Referral } \\
\text { Services, while the national government shall be } \\
\text { responsible for national referral services. } \\
\text { The referral system shall be strengthened to ensure that } \\
\text { clients at all levels gain access to appropriate skilled care. }\end{array}$ & $\begin{array}{l}\text { The overall coordination of all aspects of implementation } \\
\text { of all health related activities within schools will be the } \\
\text { responsibility of the Ministry of Education and its } \\
\text { stakeholders in collaboration with Ministry of Health who } \\
\text { will provide integrated preventive, promotive, curative } \\
\text { and rehabilitative health services. }\end{array}$ \\
\hline $\begin{array}{l}\text { Addresses the pillars of health } \\
\text { systems }\end{array}$ & $\begin{array}{l}\text { The policy addresses the building blocks of a functional } \\
\text { health system that is a critical determinant of quality of } \\
\text { services. } \\
\text { In order to provide efficient, effective and sustainable } \\
\text { adolescent sexual and reproductive health services, the } \\
\text { following building blocks as outlined: } \\
\text { 1. Health Financing and Sustainability } \\
\text { 2. Health Leadership } \\
\text { 3. Health Products and Technologies } \\
\text { 4. Health Information } \\
\text { 5. Health Workforce } \\
\text { 6. Service Delivery Systems } \\
\text { 7. Health Infrastructure }\end{array}$ & \\
\hline $\begin{array}{l}\text { Roles and responsibilities of ministry } \\
\text { of health at national level are } \\
\text { elaborated }\end{array}$ & $\begin{array}{l}\text { The policy provides for the roles of the Ministry of Health at } \\
\text { national level including: } \\
\text { Oversee and facilitate implementation of the Policy at } \\
\text { national and county levels; } \\
\text { Ensure adequate capacity in terms of staffing, equipment } \\
\text { and supplies; } \\
\text { Develop a comprehensive plan of action for the } \\
\text { implementation of the policy; } \\
\text { Disseminate the ASRH Policy; } \\
\text { Set standards and regulatory mechanisms; } \\
\text { Regulate and co-ordinate ASRH training, } \\
\text { Information sharing and service delivery; } \\
\text { Co-ordinate activities supported by development partners; }\end{array}$ & $\begin{array}{l}\text { The policy provides for the joint roles of the Ministry of } \\
\text { Education and Ministry of Health in regard to all aspects } \\
\text { of school health including: } \\
\text { Development and review of the National School Health } \\
\text { Policy and Guidelines. } \\
\text { Coordination of all School Health stakeholders, bilateral } \\
\text { and multilateral partners at the national level. } \\
\text { Planning of school health programme activities e.g. } \\
\text { school health action days. } \\
\text { Implementation of all aspects of the School Health Policy } \\
\text { in schools. } \\
\text { Supervision, monitoring and evaluation. } \\
\text { Conducting research (School-Based and community } \\
\text { linked Health Research). }\end{array}$ \\
\hline
\end{tabular}




\begin{tabular}{|c|c|c|}
\hline $\begin{array}{l}\text { Components related to prevention } \\
\text { and management of FGM/C }\end{array}$ & $\begin{array}{l}\text { National Adolescent Sexual and Reproductive Health } \\
\text { (ASRH) Policy } 2015\end{array}$ & National School Health Policy 2009 (Revised 2018) \\
\hline & $\begin{array}{l}\text { Mobilise and allocate resources for ASRH programmes; } \\
\text { Facilitate adolescent data disaggregation through revision } \\
\text { of existing data capture tools in the health facilities and } \\
\text { sensitisation of different stakeholders including the media; } \\
\text { Strengthen the school health programme. }\end{array}$ & $\begin{array}{l}\text { Capacity building of teachers and health workers on } \\
\text { school health needs. } \\
\text { Provision of technical assistance on the implementation } \\
\text { of core health activities. } \\
\text { County department of health to provide technical support } \\
\text { in the training and in-servicing of school personnel. }\end{array}$ \\
\hline $\begin{array}{l}\text { Roles and responsibilities of Ministry } \\
\text { of Health at county level are } \\
\text { elaborated }\end{array}$ & $\begin{array}{l}\text { The policy provides for the role of Ministry of Health at } \\
\text { county level including: } \\
\text { County governments are responsible for health service } \\
\text { delivery at the county level. } \\
\text { Within the devolved governance structure, the county } \\
\text { governments shall allocate resources toward } \\
\text { implementation of the ASRH Policy. } \\
\text { The planning, implementation, supervision and } \\
\text { coordination of all ASRH programme activities shall be } \\
\text { undertaken by: county health management teams, county } \\
\text { hospital management teams, sub-county health } \\
\text { management teams, primary care facility management } \\
\text { teams; and community units. } \\
\text { The county health committees, county hospital boards, } \\
\text { primary care facility management committees and } \\
\text { community health committees shall play an oversight role } \\
\text { on ASRH matters, including resource mobilisation, } \\
\text { ensuring high quality of services as well as M\&E. } \\
\text { The county and sub-county health stakeholders' forums } \\
\text { and the community dialogue days shall provide avenues for } \\
\text { partnership and public participation in ASRH issues. The } \\
\text { Ministry of Health shall ensure collaboration with key } \\
\text { departments within and outside the ministry and encourage } \\
\text { relevant agencies to mainstream ASRH issues in their core } \\
\text { functions. }\end{array}$ & \\
\hline $\begin{array}{l}\text { Multi-stakeholder mechanism of } \\
\text { implementation is highlighted }\end{array}$ & $\begin{array}{l}\text { The policy provides for a multi-sectoral approach } \\
\text { mechanism of implementation as follows: } \\
\text { The implementation of the Policy should involve other } \\
\text { ministries and state agencies namely Ministry of Education, } \\
\text { Science and Technology, National Treasury, Ministry of } \\
\text { Devolution, National Human Rights Institutions }\end{array}$ & $\begin{array}{l}\text { The policy provides for the responsibilities of the Ministry } \\
\text { of Public Health and Sanitation (now ministry of } \\
\text { Education) including: } \\
\text { - Chairs the National School Health Technical } \\
\text { Committee }\end{array}$ \\
\hline
\end{tabular}




\begin{tabular}{|c|c|c|}
\hline $\begin{array}{l}\text { Components related to prevention } \\
\text { and management of } \mathrm{FGM} / \mathrm{C}\end{array}$ & $\begin{array}{l}\text { National Adolescent Sexual and Reproductive Health } \\
\text { (ASRH) Policy } 2015\end{array}$ & National School Health Policy 2009 (Revised 2018) \\
\hline & $\begin{array}{l}\text { (Commissions), Ministry of Information Communication and } \\
\text { Technology (Communication Authority of Kenya), Law } \\
\text { Enforcement Agencies (National Police Service, Judiciary, } \\
\text { Internal Security, HIV tribunal, Office of the Director of } \\
\text { Public Prosecutions, Ministry of Labour, Social Security } \\
\text { and Services (National Council for Children Services, } \\
\text { Directorate of Children Services, National Council for } \\
\text { Persons with Disability), Parliament }\end{array}$ & 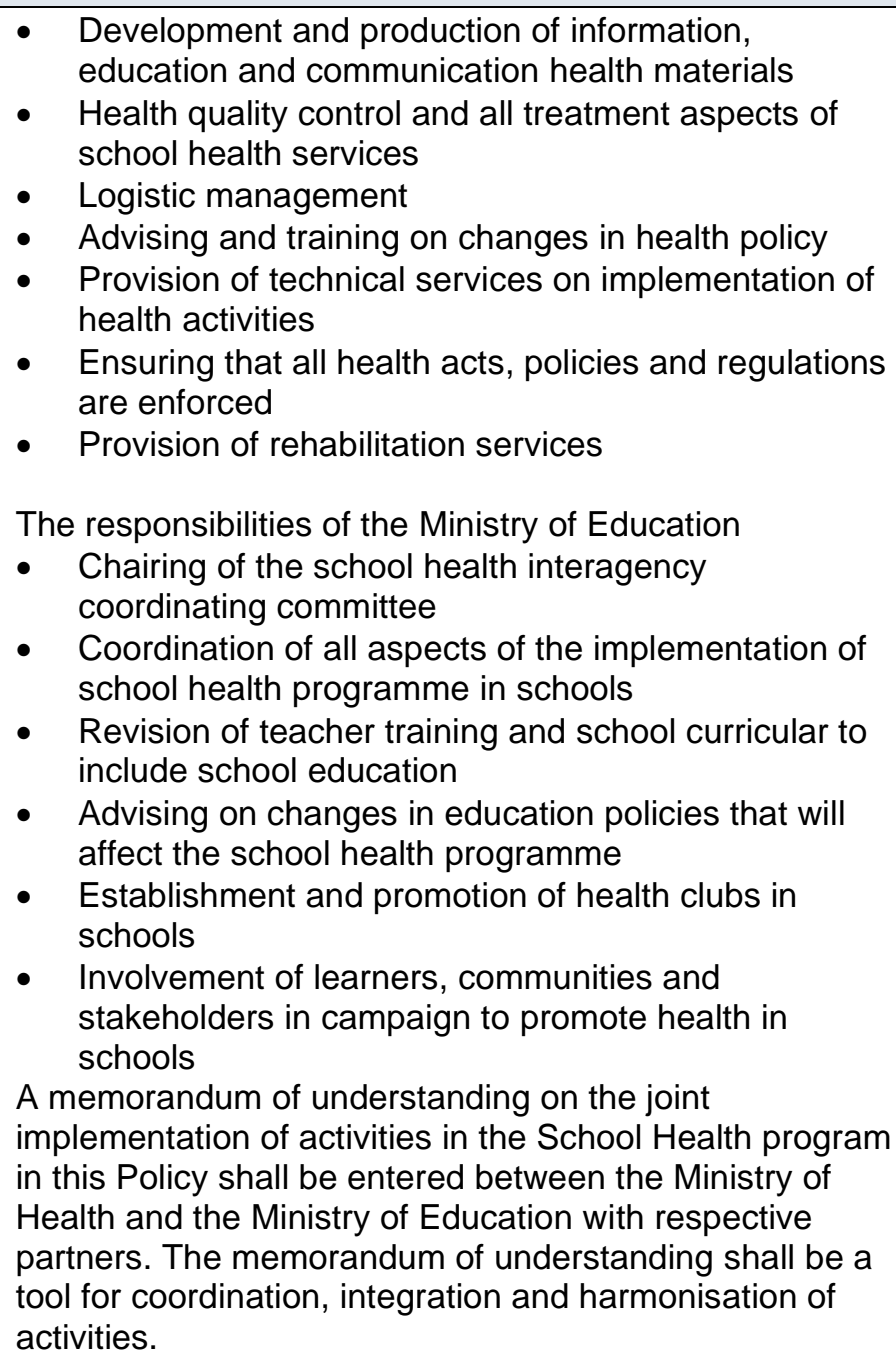 \\
\hline Research & & $\begin{array}{l}\text { In order to ensure that policies and strategies remain } \\
\text { cost-effective, competitive and current, National School } \\
\text { Health Technical Committee shall commission at least }\end{array}$ \\
\hline
\end{tabular}




\begin{tabular}{|c|c|c|}
\hline $\begin{array}{l}\text { Components related to prevention } \\
\text { and management of FGM/C }\end{array}$ & $\begin{array}{l}\text { National Adolescent Sexual and Reproductive Health } \\
\text { (ASRH) Policy } 2015\end{array}$ & \begin{tabular}{|l} 
National School Health Policy 2009 (Revised 2018) \\
\end{tabular} \\
\hline & & $\begin{array}{l}\text { one nationwide study, survey and / or evaluation on } \\
\text { school health. The study, survey and / or evaluation will } \\
\text { be used to generate a new body of knowledge and } \\
\text { information and highlight best practices in school health. } \\
\text { The findings shall be widely disseminated and utilised to } \\
\text { inform policy. }\end{array}$ \\
\hline Dissemination & & $\begin{array}{l}\text { The School Health Secretariat shall ensure that enough } \\
\text { copies are printed, and disseminated in all counties, sub } \\
\text { counties, public and private primary and public and } \\
\text { private secondary schools in Kenya. }\end{array}$ \\
\hline $\begin{array}{l}\text { The policy stipulates the role of non- } \\
\text { State Actors }\end{array}$ & $\begin{array}{l}\text { The non-state actors are identified as adolescents, NGOs, } \\
\text { civil society organisations, community-based organisations, } \\
\text { faith-based organisations and private sector, development } \\
\text { partners, communities, families and individuals, training } \\
\text { and research institutions, media, professional associations } \\
\text { and regulatory bodies }\end{array}$ & $\begin{array}{l}\text { The policy spells out the actors who include: Ministry of } \\
\text { Public health and Sanitation, Ministry of Education, } \\
\text { community around the school, the learners, } \\
\text { parents/guardians and sponsors. } \\
\text { It stipulates that there would be a memorandum of } \\
\text { understanding signed between them }\end{array}$ \\
\hline M\&E is anchored in the document & $\begin{array}{l}\text { The Ministry of Health shall provide overall strategic } \\
\text { leadership in monitoring and evaluating implementation of } \\
\text { the policy with technical assistance from a multi-sectoral } \\
\text { technical working group that includes development } \\
\text { partners. } \\
\text { An M\&E framework for assessing implementation and } \\
\text { impact shall be established based on the goals and } \\
\text { objectives of the Policy and targets set in the Plan of } \\
\text { Action. } \\
\text { The ministry and partners shall mobilise resources to } \\
\text { support M\&E of the Policy and its Plan of Action. } \\
\text { The M\&E framework for the Policy shall link to the ministry } \\
\text { institutional M\&E framework and other key M\&E } \\
\text { frameworks including the health management information } \\
\text { system (HMIS). } \\
\text { The Policy shall advocate for integration of ASRH relevant } \\
\text { indicators into the National Integrated M\&E System and } \\
\text { other relevant M\&E frameworks. } \\
\text { State and non-state actors shall align their projects and or } \\
\text { programmes to the ministry's M\&E framework. }\end{array}$ & $\begin{array}{l}\text { An M\&E system shall be developed specifying } \\
\text { mechanisms, tools and indicators in order to monitor the } \\
\text { effectiveness of the school health programme in } \\
\text { achieving health and education outcomes. } \\
\text { Partners implementing school health shall submit data to } \\
\text { the district school health coordinating committee. } \\
\text { A monitoring and evaluation system shall be developed, } \\
\text { specifying mechanisms, tools and indicators in order to } \\
\text { monitor the implementation of the School Health } \\
\text { Programmes to achieve health and educational } \\
\text { outcomes. } \\
\text { It will reflect constitutional, national target of health and } \\
\text { education priorities as elaborated in vision } 2030 . \\
\text { The Programme will utilise existing databases and } \\
\text { information systems, in particular the HMIS and NEMIS } \\
\text { from Ministry of Health and Ministry of Education } \\
\text { respectively, to keep accurate and relevant information. } \\
\text { Partners implementing school health activities shall avail } \\
\text { any data resulting from their activities to the School } \\
\text { Health Secretariat. }\end{array}$ \\
\hline
\end{tabular}




\begin{tabular}{|c|c|c|}
\hline $\begin{array}{l}\text { Components related to prevention } \\
\text { and management of FGM/C }\end{array}$ & $\begin{array}{l}\text { National Adolescent Sexual and Reproductive Health } \\
\text { (ASRH) Policy } 2015\end{array}$ & National School Health Policy 2009 (Revised 2018) \\
\hline & $\begin{array}{l}\text { The Ministry of Health shall ensure continuous monitoring } \\
\text { of the Policy implementation through routine data collection } \\
\text { using HMIS and support supervision. The Policy shall } \\
\text { promote collection, analysis and utilisation of age and sex } \\
\text { disaggregated data for adolescents. } \\
\text { The Ministry of Health shall support capacity building of } \\
\text { programme managers, planners and service providers on } \\
\text { data utilisation for decision-making. } \\
\text { The Ministry of Health shall provide technical support to } \\
\text { KNBS and other relevant research institutions to ensure } \\
\text { inclusion of ASRH indicators in periodic population-based } \\
\text { surveys and research. The M\&E of the Policy shall be } \\
\text { guided by clearly set indicators and targets. }\end{array}$ & $\begin{array}{l}\text { Indicators to be monitored } \\
\text { Right to Protection } \\
\text { Number of teachers trained on child protection } \\
\text { Percentage of violations against children reported and } \\
\text { conclusively responded to } \\
\text { Gender, Growth and Development } \\
\text { Number of members of the school community trained on } \\
\text { GBV prevention and response } \\
\text { Number of learning institutions with GBV reporting } \\
\text { mechanisms as indicated in the IEC materials } \\
\% \text { of learner and other members of school community } \\
\text { sensitised on gender issues } \\
\% \text { of learners and members of school community } \\
\text { sensitised on negative effects of cultural practices } \\
\% \text { of primary and secondary schools promoting } \\
\text { awareness on gender based violence and existing legal } \\
\text { and policy frameworks for sexual violence among } \\
\text { learners and other school community members }\end{array}$ \\
\hline
\end{tabular}


Table A4. Components relevant to health sector response to prevention and management of FGM/C in Nigerian policies

\begin{tabular}{|c|c|c|c|c|}
\hline $\begin{array}{l}\text { Components related to } \\
\text { prevention and } \\
\text { management of FGM/C }\end{array}$ & $\begin{array}{l}\text { National Gender Policy } \\
2006\end{array}$ & $\begin{array}{l}\text { National Policy on the } \\
\text { Health and Development } \\
\text { of Adolescents and } \\
\text { Young People } 2007\end{array}$ & $\begin{array}{l}\text { National Policy and Plan of } \\
\text { Action for the Elimination of } \\
\text { FGM in Nigeria 2013-2017 }\end{array}$ & $\begin{array}{l}\text { National Reproductive Health } \\
\text { Policy } 2017\end{array}$ \\
\hline $\begin{array}{l}\text { Definition and classification } \\
\text { of } F G M / C \text { is consistent with } \\
\text { WHO criteria }\end{array}$ & Not defined. & Not defined. & $\begin{array}{l}\text { Conforms to the WHO } \\
\text { definition and classification }\end{array}$ & Not defined. \\
\hline $\begin{array}{l}\text { Policy goal and FGM/C- } \\
\text { related objectives }\end{array}$ & $\begin{array}{l}\text { Goal: To promote gender } \\
\text { equity and sustainable human } \\
\text { economic development } \\
\text { FGM/C related Objectives: } \\
\text { The policy does not contain } \\
\text { any FGM/C specific } \\
\text { objectives, but FGM/C could } \\
\text { be mainstreamed into the } \\
\text { following objectives: } \\
\text { - Incorporate the principles } \\
\text { of the Convention on the } \\
\text { Elimination of all Forms of } \\
\text { Discrimination Against } \\
\text { Women (CEDAW) and } \\
\text { other global and regional } \\
\text { frameworks that support } \\
\text { gender equality and } \\
\text { women empowerment in } \\
\text { the country's legislative } \\
\text { processes } \\
\text { Promote equal } \\
\text { opportunity in all areas of } \\
\text { political, social, economic } \\
\text { life of the country for } \\
\text { women, as well as for } \\
\text { men } \\
\text { Sensitise all stakeholder } \\
\text { to their roles and }\end{array}$ & $\begin{array}{l}\text { Goal: To promote the } \\
\text { "optimal health and } \\
\text { development" of } \\
\text { adolescents and other } \\
\text { young people in Nigeria by } \\
\text { providing a "framework for } \\
\text { generating required } \\
\text { political will, mobilising } \\
\text { resources, creating a safe } \\
\text { and supportive } \\
\text { environment, fostering } \\
\text { collaborations, and } \\
\text { developing programmes" } \\
\text { FGM/C-related } \\
\text { Objectives: The policy } \\
\text { does not have any FGM/C } \\
\text { specific objectives, but } \\
\text { FGM/C issues can be } \\
\text { addressed through all of } \\
\text { its objectives: } \\
\text { - Stimulate advocacy } \\
\text { efforts for increased } \\
\text { political will and } \\
\text { resource allocation for } \\
\text { young people's health } \\
\text { and development } \\
\text { programmes and } \\
\text { interventions }\end{array}$ & $\begin{array}{l}\text { Goal: To eliminate the practice } \\
\text { of FGM/C in Nigeria in order to } \\
\text { improve the health and quality } \\
\text { of life of girls and women. } \\
\text { FGM/C-related Objectives: } \\
\text { - To reduce the prevalence } \\
\text { of female genital mutilation } \\
\text { in Nigeria } \\
\text { - To promote community } \\
\text { behavioural change } \\
\text { initiatives towards } \\
\text { elimination of FGM in } \\
\text { Nigeria } \\
\text { - To establish a legal } \\
\text { framework for the } \\
\text { elimination of FGM at } \\
\text { National and State levels } \\
\text { - To strengthen system for } \\
\text { research, monitoring, and } \\
\text { evaluation towards the } \\
\text { elimination of FGM } \\
\text { Targets: } \\
\text { - Strengthen existing } \\
\text { relevant systems } \\
\text { Strengthen inter-sectoral } \\
\text { collaboration }\end{array}$ & $\begin{array}{l}\text { Goal: To provide a framework of } \\
\text { actions and guidance required for } \\
\text { the attainment of complete SRH } \\
\text { and wellbeing for all Nigerians } \\
\text { throughout their life cycle. } \\
\text { FGM/C-related Objectives: } \\
\text { To reduce the incidence and } \\
\text { prevalence of female genital } \\
\text { mutilation and provide } \\
\text { appropriate care for those } \\
\text { affected }\end{array}$ \\
\hline
\end{tabular}




\begin{tabular}{|c|c|c|c|c|}
\hline $\begin{array}{l}\text { Components related to } \\
\text { prevention and } \\
\text { management of FGM/C }\end{array}$ & $\begin{array}{l}\text { National Gender Policy } \\
2006\end{array}$ & $\begin{array}{l}\text { National Policy on the } \\
\text { Health and Development } \\
\text { of Adolescents and } \\
\text { Young People } 2007\end{array}$ & $\begin{array}{l}\text { National Policy and Plan of } \\
\text { Action for the Elimination of } \\
\text { FGM in Nigeria 2013-2017 }\end{array}$ & $\begin{array}{l}\text { National Reproductive Health } \\
\text { Policy } 2017\end{array}$ \\
\hline & $\begin{array}{l}\text { responsibilities in } \\
\text { adopting the priorities of } \\
\text { this policy }\end{array}$ & $\begin{array}{l}\text { Enhance technical } \\
\text { capacity, } \\
\text { interventions, } \\
\text { collaboration and } \\
\text { coordination for the } \\
\text { promotion of the } \\
\text { health and } \\
\text { development of young } \\
\text { people } \\
\text { Increase the access of } \\
\text { young people to } \\
\text { quality information, } \\
\text { education and youth- } \\
\text { friendly services; } \\
\text { Promote the } \\
\text { meaningful } \\
\text { participation of young } \\
\text { people, families, } \\
\text { communities, } \\
\text { organisations and } \\
\text { institutions in young } \\
\text { people health and } \\
\text { development issues } \\
\text { and programmes }\end{array}$ & $\begin{array}{l}\text { - Reduce proportion of } \\
\text { women and girls } \\
\text { undergoing FGM } \\
\text { - Increase the number of } \\
\text { primary, secondary and } \\
\text { tertiary health care } \\
\text { facilities that provide care, } \\
\text { counselling and support to } \\
\text { affected female persons } \\
\text { - Eradicate medicalisation of } \\
\text { FGM in Nigeria by } 2015 \\
\text { - Increase the proportion of } \\
\text { women and men with } \\
\text { knowledge about the } \\
\text { harmful consequences of } \\
\text { FGM } \\
\text { Reduce the proportion of } \\
\text { women and men who } \\
\text { support the continuation of } \\
\text { FGM } \\
\text { Support advocacy for the } \\
\text { passage of the VAPP Bill } \\
\text { which encompasses FGM, } \\
\text { by } 2015 \\
\text { Increase the number of } \\
\text { states with legislation } \\
\text { against FGM } \\
\text { Achieve nationwide } \\
\text { sensitisation campaign on } \\
\text { the laws supporting FGM } \\
\text { elimination programmes } \\
\text { by } 2017 \text { Federal and state } \\
\text { governments have } \\
\text { functioning FGM }\end{array}$ & \\
\hline
\end{tabular}




\begin{tabular}{|c|c|c|c|c|}
\hline $\begin{array}{l}\text { Components related to } \\
\text { prevention and } \\
\text { management of FGM/C }\end{array}$ & $\begin{array}{l}\text { National Gender Policy } \\
2006\end{array}$ & $\begin{array}{l}\text { National Policy on the } \\
\text { Health and Development } \\
\text { of Adolescents and } \\
\text { Young People } 2007\end{array}$ & $\begin{array}{l}\text { National Policy and Plan of } \\
\text { Action for the Elimination of } \\
\text { FGM in Nigeria 2013-2017 }\end{array}$ & $\begin{array}{l}\text { National Reproductive Health } \\
\text { Policy } 2017\end{array}$ \\
\hline & & & $\begin{array}{l}\text { elimination programmes } \\
\text { by } 2017 \\
\text { - } \quad \text { Identification of } \\
\text { appropriate indicators and } \\
\text { development of relevant } \\
\text { data collection tools on } \\
\text { FGM elimination for } \\
\text { integration into the NHMIS } \\
\text { - Institutionalisation of FGM } \\
\text { issues into the national } \\
\text { agenda through } \\
\text { incorporation into the } \\
\text { National Strategic Health } \\
\text { Development Plan and } \\
\text { Joint Annual Review } \\
\text { Capacity building for M\&E } \\
\text { to adequately address } \\
\text { gaps in knowledge and } \\
\text { skills for accurate data } \\
\text { collection and reporting } \\
\text { Establishment of quality } \\
\text { assurance mechanism for } \\
\text { elimination of FGM by } \\
2017 \\
\text { - Supporting research on } \\
\text { identified gaps for the } \\
\text { elimination of FGM by } \\
2017 \\
\text { Establishment of a system } \\
\text { for regular documentation, } \\
\text { dissemination, and easy } \\
\text { access to information on } \\
\text { FGM by } 2017 \text {. } \\
\end{array}$ & \\
\hline
\end{tabular}




\begin{tabular}{|c|c|c|c|c|}
\hline $\begin{array}{l}\text { Components related to } \\
\text { prevention and } \\
\text { management of FGM/C }\end{array}$ & $\begin{array}{l}\text { National Gender Policy } \\
2006\end{array}$ & $\begin{array}{l}\text { National Policy on the } \\
\text { Health and Development } \\
\text { of Adolescents and } \\
\text { Young People } 2007\end{array}$ & $\begin{array}{l}\text { National Policy and Plan of } \\
\text { Action for the Elimination of } \\
\text { FGM in Nigeria 2013-2017 }\end{array}$ & $\begin{array}{l}\text { National Reproductive Health } \\
\text { Policy } 2017\end{array}$ \\
\hline $\begin{array}{l}\text { Contains guiding principles } \\
\text { relevant to addressing } \\
\text { FGM/C }\end{array}$ & $\begin{array}{l}\text { Yes. These principles are: } \\
\text { Making gender analysis } \\
\text { an integral part of all } \\
\text { policy articulation, } \\
\text { implementation and } \\
\text { evaluation; } \\
\text { All stakeholders are to } \\
\text { take a role in the } \\
\text { mandate for gender } \\
\text { equity and equality; } \\
\text { Policy implementation is } \\
\text { to depend on a cultural } \\
\text { re-orientation that will be } \\
\text { supported by policies and } \\
\text { programmes of gender } \\
\text { education, sensitisation, } \\
\text { motivation and } \\
\text { responsiveness, rather } \\
\text { than only through } \\
\text { legislations; } \\
\text { Women empowerment is } \\
\text { considered as integral to } \\
\text { the achievement of } \\
\text { gender equality. }\end{array}$ & $\begin{array}{l}\text { Yes. These principles are: } \\
\text { young people as a human } \\
\text { resource, rights-based } \\
\text { approach, diversity of } \\
\text { young people's needs and } \\
\text { situation, gender equity } \\
\text { and equality, cultural } \\
\text { sensitivity, participatory } \\
\text { and consultative, } \\
\text { evidence-based. }\end{array}$ & $\begin{array}{l}\text { Yes. These principles are: } \\
\text { human dignity, gender } \\
\text { equality, trust, participation, } \\
\text { inclusion and cultural respect. }\end{array}$ & $\begin{array}{l}\text { Yes. These principles are: rights- } \\
\text { based approach, equity-driven, } \\
\text { participatory and consultative, } \\
\text { evidence-based, gender and age- } \\
\text { responsiveness, cultural } \\
\text { sensitivity, partnership and multi- } \\
\text { sectoral approach, universality, } \\
\text { adolescent-focus, life-cycle } \\
\text { approach, country-led, financing } \\
\text { and accountability }\end{array}$ \\
\hline $\begin{array}{l}\text { Highlights policy } \\
\text { context/environment } \\
\text { concerning FGM/C }\end{array}$ & $\begin{array}{l}\text { Although, the policy does not } \\
\text { explicitly discuss the policy } \\
\text { context/environment } \\
\text { concerning FGM/C, it } \\
\text { describes the existing } \\
\text { national and international } \\
\text { policy context in which the } \\
\text { gender policy is situated, } \\
\text { which is relevant for FGM/C. }\end{array}$ & $\begin{array}{l}\text { The policy does not } \\
\text { specifically highlight the } \\
\text { policy context or } \\
\text { environment concerning } \\
\text { FGM/C but it does situate } \\
\text { itself with reference to } \\
\text { several international and } \\
\text { national policies that are } \\
\text { relevant to FGM/C }\end{array}$ & $\begin{array}{l}\text { The policy states that the } \\
\text { elimination of FGM/C should } \\
\text { be explicitly addressed in the } \\
\text { national strategic health } \\
\text { development plan as a } \\
\text { "medico-social issue." The } \\
\text { policy states that its } \\
\text { development is within the } \\
\text { framework of the National }\end{array}$ & $\begin{array}{l}\text { The policy states that it has been } \\
\text { formulated within the context of } \\
\text { other relevant and important } \\
\text { national and international } \\
\text { development policies and } \\
\text { frameworks including the National } \\
\text { Policy and Plan of Action on } \\
\text { Elimination of Female Genital } \\
\text { Mutilation 2013-2017. }\end{array}$ \\
\hline
\end{tabular}




\begin{tabular}{|c|c|c|c|c|}
\hline $\begin{array}{l}\text { Components related to } \\
\text { prevention and } \\
\text { management of FGM/C }\end{array}$ & $\begin{array}{l}\text { National Gender Policy } \\
2006\end{array}$ & $\begin{array}{l}\text { National Policy on the } \\
\text { Health and Development } \\
\text { of Adolescents and } \\
\text { Young People } 2007\end{array}$ & $\begin{array}{l}\text { National Policy and Plan of } \\
\text { Action for the Elimination of } \\
\text { FGM in Nigeria 2013-2017 }\end{array}$ & $\begin{array}{l}\text { National Reproductive Health } \\
\text { Policy } 2017\end{array}$ \\
\hline & $\begin{array}{l}\text { It refers to a myriad of } \\
\text { international and regional } \\
\text { human rights and } \\
\text { development instruments and } \\
\text { agreements (for example } \\
\text { CEDAW, the Protocol on the } \\
\text { Rights of Women in Africa, } \\
\text { and the Beijing Platform of } \\
\text { Action and the Millennium } \\
\text { Development Goals). }\end{array}$ & $\begin{array}{l}\text { including the following: } \\
1990 \text { Convention on the } \\
\text { Rights of the Child, } \\
\text { CEDAW, the Beijing } \\
\text { Platform for Action, the } \\
1994 \text { International } \\
\text { Conference on Population } \\
\text { and Development, the } \\
1990 \text { Organisation of } \\
\text { African Unity Charter on } \\
\text { the Rights and Welfare of } \\
\text { the Child, the Nigerian } \\
\text { Constitution, the Child } \\
\text { Rights Act, National } \\
\text { Reproductive Health } \\
\text { Policy, the revised } \\
\text { National Health Policy, etc. }\end{array}$ & $\begin{array}{l}\text { Gender Policy, National Health } \\
\text { Policy, National Health } \\
\text { Strategic Development Plan as } \\
\text { well as other existing health } \\
\text { policies and strategies in } \\
\text { Nigeria. Additionally, it is in } \\
\text { line with international human } \\
\text { rights instruments that Nigeria } \\
\text { has signed specifically the } \\
\text { United Nations Convention on } \\
\text { the Rights of the Child and } \\
\text { CEDAW. It also supports the } \\
\text { World Health Assembly } \\
\text { Resolution (WHA } 47.10) \text { on } \\
\text { traditional practices harmful to } \\
\text { the health of women and } \\
\text { children, and WHO policy on } \\
\text { the non-medicalisation of } \\
\text { FGM/C. }\end{array}$ & \\
\hline $\begin{array}{l}\text { Provides situation analysis } \\
\text { of } F G M / C\end{array}$ & $\begin{array}{l}\text { The policy does not provide a } \\
\text { situation analysis on FGM/C } \\
\text { but mentions FGM/C as one } \\
\text { of the harmful traditional } \\
\text { practices that need to be } \\
\text { eliminated to ensure the } \\
\text { protection of the rights of the } \\
\text { girl child. It also describes } \\
\text { FGM/C as a harmful practice } \\
\text { meant to control women's } \\
\text { sexuality that leads to "great } \\
\text { suffering" and goes on further } \\
\text { to emphasise that FGM/C is a } \\
\text { violation of basic rights and a } \\
\text { "major life-long risk to } \\
\text { women's health". Under its }\end{array}$ & $\begin{array}{l}\text { The policy does not } \\
\text { provide a situation } \\
\text { analysis on FGM/C but in } \\
\text { its overall analysis of } \\
\text { adolescent health and } \\
\text { development in Nigeria it } \\
\text { includes FGM/C as one of } \\
\text { the major forms of sexual } \\
\text { and reproductive rights } \\
\text { violations affecting young } \\
\text { people. }\end{array}$ & $\begin{array}{l}\text { The policy provides an } \\
\text { evidence-based situation } \\
\text { analysis of FGM/C based on } \\
\text { major findings from the } \\
\text { following surveys: } \\
\text { 1. A national survey on } \\
\text { female circumcision by the } \\
\text { National Association of } \\
\text { Nigeria Nurses and } \\
\text { Midwives (1985 and 1996) } \\
\text { 2. Community Based } \\
\text { Knowledge, Attitude, and } \\
\text { Practice studies from } 22 \\
\text { states (1996) by the Inter- } \\
\text { African Committee on }\end{array}$ & $\begin{array}{l}\text { The policy provides a brief } \\
\text { situation analysis of FGM/C in } \\
\text { Nigeria based on the Nigeria } \\
\text { Demography and Health Surveys } \\
2008 \text { and } 2013\end{array}$ \\
\hline
\end{tabular}




\begin{tabular}{|c|c|c|c|c|}
\hline $\begin{array}{l}\text { Components related to } \\
\text { prevention and } \\
\text { management of FGM/C }\end{array}$ & $\begin{array}{l}\text { National Gender Policy } \\
2006\end{array}$ & $\begin{array}{l}\text { National Policy on the } \\
\text { Health and Development } \\
\text { of Adolescents and } \\
\text { Young People } 2007\end{array}$ & $\begin{array}{l}\text { National Policy and Plan of } \\
\text { Action for the Elimination of } \\
\text { FGM in Nigeria 2013-2017 }\end{array}$ & $\begin{array}{l}\text { National Reproductive Health } \\
\text { Policy } 2017\end{array}$ \\
\hline & $\begin{array}{l}\text { priority area on gender-based } \\
\text { violence, it describes an } \\
\text { unreferenced national study } \\
\text { that that was commissioned } \\
\text { to document FGM/C. }\end{array}$ & & $\begin{array}{l}\text { Harmful Traditional } \\
\text { Practices } \\
\text { 3. The National Baseline } \\
\text { Survey on harmful and } \\
\text { positive traditional } \\
\text { practices affecting women } \\
\text { and girls in Nigeria } \\
\text { conducted from } 1996 \text { to } \\
1997 \\
\text { 4. The National Population } \\
\text { Commission Report } 2005 \\
\text { 5. The } 2008 \text { Nigeria } \\
\text { Demographic and Health } \\
\text { Survey (NDHS). }\end{array}$ & \\
\hline $\begin{array}{l}\text { Priority areas and actions } \\
\text { related to FGM/C } \\
\text { addressed by the policy }\end{array}$ & $\begin{array}{l}\text { The document highlights } \\
\text { sixteen sectoral priority areas } \\
\text { for policy and action with the } \\
\text { following three specifically } \\
\text { mentioning FGM/C: } \\
\text { - Culture, family and } \\
\text { socialisation } \\
\text { Policy goal is to } \\
\text { eliminate } \\
\text { cultural/religious } \\
\text { gender-based biases } \\
\text { and harmful cultural } \\
\text { and religious } \\
\text { practices which } \\
\text { reproduce } \\
\text { inequalities in gender } \\
\text { role relations in the } \\
\text { Nigerian society and } \\
\text { thereby give a } \\
\text { subordinate status to }\end{array}$ & $\begin{array}{l}\text { The document has SRH } \\
\text { and rights as one of its } \\
\text { nine key intervention areas } \\
\text { and explicitly discusses } \\
\text { FGM/C in one of its } \\
\text { targets. With this target the } \\
\text { policy seeks to eliminate } \\
\text { the incidence of FGM/C } \\
\text { among young people by } \\
\text { 2015. Other targets } \\
\text { relevant to FGM/C } \\
\text { prevention and } \\
\text { management by the health } \\
\text { sector are "to increase the } \\
\text { proportion of young people } \\
\text { who have access to } \\
\text { accurate and } \\
\text { comprehensive } \\
\text { reproductive health } \\
\text { information and services" } \\
\text { and to "increase access of }\end{array}$ & $\begin{array}{l}\text { See plans of action/strategic } \\
\text { frameworks section below, } \\
\text { Table } 7 \text {. }\end{array}$ & $\begin{array}{l}\text { The policy has eight priority areas } \\
\text { of focus. Achieving gender equality } \\
\text { and elimination of all forms of } \\
\text { discrimination is the only key } \\
\text { priority area that has an objective } \\
\text { that explicitly mentions FGM/C. } \\
\text { This priority area seeks to achieve } \\
\text { its aims by providing appropriate } \\
\text { SRH information and creating an } \\
\text { enabling environment for } \\
\text { eliminating harmful practices and } \\
\text { rights violations. }\end{array}$ \\
\hline
\end{tabular}




\begin{tabular}{|c|c|c|c|c|}
\hline $\begin{array}{l}\text { Components related to } \\
\text { prevention and } \\
\text { management of FGM/C }\end{array}$ & $\begin{array}{l}\text { National Gender Policy } \\
2006\end{array}$ & $\begin{array}{l}\text { National Policy on the } \\
\text { Health and Development } \\
\text { of Adolescents and } \\
\text { Young People } 2007\end{array}$ & $\begin{array}{l}\text { National Policy and Plan of } \\
\text { Action for the Elimination of } \\
\text { FGM in Nigeria 2013-2017 }\end{array}$ & $\begin{array}{l}\text { National Reproductive Health } \\
\text { Policy } 2017\end{array}$ \\
\hline & $\begin{array}{l}\text { women compared to } \\
\text { men } \\
\text { Implementing existing } \\
\text { and enacting new } \\
\text { state laws prohibiting } \\
\text { FGM/C is one of the } \\
\text { strategies to } \\
\text { achieving this goal. } \\
\text { - Gender based-violence } \\
\text { FGM/C is discussed } \\
\text { as a form of gender- } \\
\text { based violence in the } \\
\text { description of this } \\
\text { priority area. } \\
\text { Policy goal is to } \\
\text { eradicate all forms of } \\
\text { gender-based } \\
\text { violence and } \\
\text { discrimination and } \\
\text { ensure that women } \\
\text { and men enjoy the } \\
\text { same rights } \\
\text { irrespective of their } \\
\text { gender, age, } \\
\text { ethnicity, religion, and } \\
\text { class } \\
\text { Health and reproductive } \\
\text { services } \\
\text { Aimed at improving } \\
\text { health services and } \\
\text { to enhance better } \\
\text { reproductive health } \\
\text { care for all and in } \\
\text { particular women, }\end{array}$ & $\begin{array}{l}\text { all categories of young } \\
\text { people to comprehensive } \\
\text { youth-friendly health } \\
\text { services." Additionally, } \\
\text { although not speaking } \\
\text { directly to FGM/C, the } \\
\text { policy mentions "capacity } \\
\text { building for health care } \\
\text { workers, teachers, and } \\
\text { other stakeholders dealing } \\
\text { with young people" as one } \\
\text { of the key strategies of its } \\
\text { implementation. These } \\
\text { targets and strategies } \\
\text { would be relevant for } \\
\text { addressing the prevention } \\
\text { of FGM/C and } \\
\text { management of } \\
\text { complications among girls } \\
\text { and young women in the } \\
\text { health sector. }\end{array}$ & & \\
\hline
\end{tabular}




\begin{tabular}{|c|c|c|c|c|}
\hline $\begin{array}{l}\text { Components related to } \\
\text { prevention and } \\
\text { management of } \mathrm{FGM} / \mathrm{C}\end{array}$ & $\begin{array}{l}\text { National Gender Policy } \\
2006\end{array}$ & $\begin{array}{l}\text { National Policy on the } \\
\text { Health and Development } \\
\text { of Adolescents and } \\
\text { Young People } 2007\end{array}$ & $\begin{array}{l}\text { National Policy and Plan of } \\
\text { Action for the Elimination of } \\
\text { FGM in Nigeria 2013-2017 }\end{array}$ & $\begin{array}{l}\text { National Reproductive Health } \\
\text { Policy } 2017\end{array}$ \\
\hline & $\begin{array}{l}\text { Although there are no } \\
\text { FGM/C specific } \\
\text { strategies to achieve } \\
\text { this goal, the policy } \\
\text { mentions several } \\
\text { strategies that would } \\
\text { be relevant to } \\
\text { women/girls being } \\
\text { able to receive } \\
\text { appropriate } \\
\text { management for } \\
\text { FGM/C } \\
\text { complications. These } \\
\text { include: making a } \\
\text { comprehensive and } \\
\text { full range of } \\
\text { reproductive health } \\
\text { care services, } \\
\text { accessible, } \\
\text { affordable, } \\
\text { acceptable, and } \\
\text { convenient to } \\
\text { women, men, and } \\
\text { adolescents (girls } \\
\text { and boys); making } \\
\text { health care } \\
\text { affordable, and } \\
\text { accessible to all } \\
\text { through upgrading of } \\
\text { primary and } \\
\text { secondary health } \\
\text { care facilities; } \\
\text { instituting M\&E } \\
\text { systems for user- } \\
\text { centred services to }\end{array}$ & & & \\
\hline
\end{tabular}




\begin{tabular}{|c|c|c|c|c|}
\hline $\begin{array}{l}\text { Components related to } \\
\text { prevention and } \\
\text { management of FGM/C }\end{array}$ & $\begin{array}{l}\text { National Gender Policy } \\
2006\end{array}$ & $\begin{array}{l}\text { National Policy on the } \\
\text { Health and Development } \\
\text { of Adolescents and } \\
\text { Young People } 2007\end{array}$ & $\begin{array}{l}\text { National Policy and Plan of } \\
\text { Action for the Elimination of } \\
\text { FGM in Nigeria 2013-2017 }\end{array}$ & $\begin{array}{l}\text { National Reproductive Health } \\
\text { Policy } 2017\end{array}$ \\
\hline & $\begin{array}{l}\text { detect, prevent and } \\
\text { control gender-based } \\
\text { abuses, and ensure } \\
\text { quality of service; } \\
\text { improving logistical } \\
\text { systems; and build a } \\
\text { strong and effective } \\
\text { referral mechanism }\end{array}$ & & & \\
\hline $\begin{array}{l}\text { FGM/C related roles and } \\
\text { responsibilities of health } \\
\text { sector actors }\end{array}$ & $\begin{array}{l}\text { The gender policy does not } \\
\text { explicitly state the health } \\
\text { sector's roles and } \\
\text { responsibilities in policy } \\
\text { implementation. The health } \\
\text { sector's role is only implied } \\
\text { from an emphasis on gender } \\
\text { being treated as a cross- } \\
\text { cutting issue and that the } \\
\text { Gender Desk Officers of line } \\
\text { Ministries other than the } \\
\text { Federal Ministry of Women } \\
\text { Affairs are responsible for } \\
\text { mainstreaming gender in their } \\
\text { respective ministries' } \\
\text { mandate. }\end{array}$ & $\begin{array}{l}\text { The policy recognises that } \\
\text { a multi-sectoral response } \\
\text { is necessary for its } \\
\text { successful implementation } \\
\text { and it goes on to describe } \\
\text { the roles and } \\
\text { responsibilities of the } \\
\text { different sectors including } \\
\text { the health sector, which it } \\
\text { describes as having an } \\
\text { important lead role in } \\
\text { ensuring that there is an } \\
\text { enabling environment for } \\
\text { policy implementation. The } \\
\text { health sector has several } \\
\text { responsibilities which } \\
\text { would be relevant to } \\
\text { strengthening the capacity } \\
\text { of health workers to } \\
\text { provide FGM/C prevention } \\
\text { and management } \\
\text { services. These } \\
\text { responsibilities are the } \\
\text { following: } \\
\text { - develop and } \\
\text { communicate the } \\
\text { national strategic plan }\end{array}$ & $\begin{array}{l}\text { The health sector takes the } \\
\text { lead in implementing the } \\
\text { strategies and activities of the } \\
\text { policy and through the FMOH } \\
\text { is expected to seek and } \\
\text { engage in inter-sectoral } \\
\text { collaboration with other } \\
\text { sectors, ministries, } \\
\text { departments, and agencies, } \\
\text { and all stakeholders while } \\
\text { implementing programmes } \\
\text { with the aim of eliminating } \\
\text { FGM/C in Nigeria. The policy } \\
\text { outlines the roles and } \\
\text { responsibilities for the different } \\
\text { FGM/C response coordinating } \\
\text { mechanisms (FGM advisory } \\
\text { committee and FGM technical } \\
\text { committee) at federal, state, } \\
\text { and local government area/ } \\
\text { community level. The FMOH, } \\
\text { State Ministry of Health, and } \\
\text { the Head of the Department of } \\
\text { Health serve as the conveners } \\
\text { of each committee at federal, } \\
\text { state, and local government }\end{array}$ & $\begin{array}{l}\text { The policy states that reproductive } \\
\text { health programme delivery rests } \\
\text { on the pillar of inter-sectoral } \\
\text { partnership and goes on to provide } \\
\text { detailed roles and responsibilities } \\
\text { for different sectors, including } \\
\text { health sector actors namely the } \\
\text { FMOH, State Ministries of Health, } \\
\text { the local government, health } \\
\text { professional associations, health } \\
\text { professional regulatory bodies, and } \\
\text { lay health workers. Of note, the } \\
\text { FMOH is responsible for providing } \\
\text { overall strategic support for the } \\
\text { implementation of the policy. }\end{array}$ \\
\hline
\end{tabular}




\begin{tabular}{|c|c|c|c|c|}
\hline $\begin{array}{l}\text { Components related to } \\
\text { prevention and } \\
\text { management of FGM/C }\end{array}$ & $\begin{array}{l}\text { National Gender Policy } \\
2006\end{array}$ & $\begin{array}{l}\text { National Policy on the } \\
\text { Health and Development } \\
\text { of Adolescents and } \\
\text { Young People } 2007\end{array}$ & $\begin{array}{l}\text { National Policy and Plan of } \\
\text { Action for the Elimination of } \\
\text { FGM in Nigeria 2013-2017 }\end{array}$ & $\begin{array}{l}\text { National Reproductive Health } \\
\text { Policy } 2017\end{array}$ \\
\hline & & $\begin{array}{l}\text { and implementation } \\
\text { frameworks for health } \\
\text { workforce } \\
\text { development for } \\
\text { young people-targeted } \\
\text { health services and } \\
\text { expansion of } \\
\text { adolescent/youth- } \\
\text { friendly health } \\
\text { services; } \\
\text { set standards, develop } \\
\text { guidelines and make } \\
\text { available tools for } \\
\text { training and other } \\
\text { human resources } \\
\text { development activities } \\
\text { nationwide; and } \\
\text { develop, widely } \\
\text { disseminate and } \\
\text { periodically review } \\
\text { national standards, } \\
\text { minimum health } \\
\text { packages, tools, } \\
\text { instruments, and } \\
\text { materials in support of } \\
\text { adolescent/youth } \\
\text { friendly health } \\
\text { services in Nigeria, } \\
\text { including clinical } \\
\text { counselling, and } \\
\text { health communication } \\
\text { services. }\end{array}$ & $\begin{array}{l}\text { area/community level } \\
\text { respectively. }\end{array}$ & \\
\hline
\end{tabular}




\begin{tabular}{|c|c|c|c|c|}
\hline $\begin{array}{l}\text { Components related to } \\
\text { prevention and } \\
\text { management of FGM/C }\end{array}$ & $\begin{array}{l}\text { National Gender Policy } \\
2006\end{array}$ & $\begin{array}{l}\text { National Policy on the } \\
\text { Health and Development } \\
\text { of Adolescents and } \\
\text { Young People } 2007 \\
\end{array}$ & $\begin{array}{l}\text { National Policy and Plan of } \\
\text { Action for the Elimination of } \\
\text { FGM in Nigeria 2013-2017 }\end{array}$ & $\begin{array}{l}\text { National Reproductive Health } \\
\text { Policy } 2017\end{array}$ \\
\hline $\begin{array}{l}\text { Coordination mechanism for } \\
\text { managing/implementing } \\
\text { policy }\end{array}$ & $\begin{array}{l}\text { The Federal Executive } \\
\text { Council seats at the top of the } \\
\text { gender equality institutional } \\
\text { framework and sets national } \\
\text { policy goals and targets, and, } \\
\text { makes overarching policy } \\
\text { pronouncements on gender } \\
\text { equality and women } \\
\text { empowerment. The structures } \\
\text { and institutions involved in } \\
\text { institutionalising gender } \\
\text { issues are coordinated by the } \\
\text { Federal Ministry of Women } \\
\text { Affairs, which has a seat at } \\
\text { the Federal Executive } \\
\text { Council. National } \\
\text { Consultative and } \\
\text { Coordinating Committee on } \\
\text { Gender Equality (includes } \\
\text { gender experts from } \\
\text { academia and observer } \\
\text { members from development } \\
\text { partners) is responsible for } \\
\text { coordinating all efforts on } \\
\text { gender mainstreaming in the } \\
\text { different line Ministries. The } \\
\text { National Technical team of } \\
\text { Gender Experts (expanded to } \\
\text { include independent gender } \\
\text { consultants) is responsible for } \\
\text { gender mainstreaming at } \\
\text { sector level. }\end{array}$ & $\begin{array}{l}\text { The FMOH provides } \\
\text { overall strategic support } \\
\text { for the implementation of } \\
\text { the policy. It also } \\
\text { establishes and supports } \\
\text { the operations of a multi- } \\
\text { disciplinary, multi-sectoral } \\
\text { Technical Advisory Group } \\
\text { - the } \\
\text { National Adolescent } \\
\text { Health and Development } \\
\text { Working Group } \\
\text { (NAHDWG) arms } \\
\text { of the FMOH and its } \\
\text { agencies, other ministries, } \\
\text { parastatals, } \\
\text { youth-led and adolescent- } \\
\text { serving } \\
\text { governmental } \\
\text { organisations, the } \\
\text { academia, research } \\
\text { bodies, private institutions, } \\
\text { services. } \\
\text { religious bodies, social } \\
\text { welfare institutions and } \\
\text { organisations working with } \\
\text { mentally/physically } \\
\text { challenged adolescents. }\end{array}$ & $\begin{array}{l}\text { Implementation of the policy is } \\
\text { driven by two major } \\
\text { committees, the FGM Advisory } \\
\text { Committee and the FGM } \\
\text { Technical Committee. Both } \\
\text { committees are meant to be } \\
\text { established at Federal, State, } \\
\text { and Local Government Levels } \\
\text { and are convened and led by } \\
\text { the FMOH, State Ministry of } \\
\text { Health, and Department of } \\
\text { Health at their respective level } \\
\text { of governance. Membership of } \\
\text { the committees include } \\
\text { representatives from the } \\
\text { health sector affiliated with the } \\
\text { following bodies: health } \\
\text { professional associations, the } \\
\text { health professional regulatory } \\
\text { bodies, the National and State } \\
\text { Primary Health Care } \\
\text { Development Agencies, and } \\
\text { the State Hospital } \\
\text { Management Board. }\end{array}$ & $\begin{array}{l}\text { The National Reproductive Health } \\
\text { Technical Working Group, a multi- } \\
\text { disciplinary and multi-sectoral } \\
\text { technical advisory group } \\
\text { coordinates policy implementation. }\end{array}$ \\
\hline$M \& E$ & $\begin{array}{l}\text { The Federal Ministry of } \\
\text { Women Affairs, through } \\
\text { special committees and }\end{array}$ & $\begin{array}{l}\text { The health sector is tasked } \\
\text { with reviewing, monitoring } \\
\text { and evaluating policies }\end{array}$ & $\begin{array}{l}\text { The policy's fourth objective is } \\
\text { to strengthen system for } \\
\text { research, M\&E towards the }\end{array}$ & $\begin{array}{l}\text { The Reproductive Health Division } \\
\text { of the Department of Family } \\
\text { Health, FMOH will collect regular }\end{array}$ \\
\hline
\end{tabular}




\begin{tabular}{|c|c|c|c|c|}
\hline $\begin{array}{l}\text { Components related to } \\
\text { prevention and } \\
\text { management of FGM/C }\end{array}$ & $\begin{array}{l}\text { National Gender Policy } \\
2006\end{array}$ & $\begin{array}{l}\text { National Policy on the } \\
\text { Health and Development } \\
\text { of Adolescents and } \\
\text { Young People } 2007\end{array}$ & $\begin{array}{l}\text { National Policy and Plan of } \\
\text { Action for the Elimination of } \\
\text { FGM in Nigeria 2013-2017 }\end{array}$ & $\begin{array}{l}\text { National Reproductive Health } \\
\text { Policy } 2017\end{array}$ \\
\hline & $\begin{array}{l}\text { Agencies, especially National } \\
\text { Centre for Women } \\
\text { Development is tasked with } \\
\text { providing guidelines for } \\
\text { collecting data on monitoring } \\
\text { indicators from government } \\
\text { departments, the private } \\
\text { sector, and civil society } \\
\text { organisations. The Ministry is } \\
\text { expected to hold an annual } \\
\text { M\&E meeting with all } \\
\text { stakeholders and to } \\
\text { undertake an annual review } \\
\text { of M\&E indicators. The } \\
\text { gender-aware M\&E tools } \\
\text { developed by the National } \\
\text { Planning Commission are } \\
\text { expected to guide the } \\
\text { operations of the M\&E } \\
\text { framework for the National } \\
\text { Gender Policy, which } \\
\text { includes frameworks for } \\
\text { gender sensitive M\&E. }\end{array}$ & $\begin{array}{l}\text { and programmes on young } \\
\text { people's health and } \\
\text { development nationwide to } \\
\text { ensure that objectives are } \\
\text { achieved but the policy } \\
\text { itself does not include a } \\
\text { mechanism for monitoring } \\
\text { policy implementation or } \\
\text { identify indicators for } \\
\text { assessing programme } \\
\text { success. }\end{array}$ & $\begin{array}{l}\text { elimination of FGM. It also } \\
\text { includes two targets that are } \\
\text { important for M\&E which are: } \\
\text { capacity building for M\&E to } \\
\text { adequately address gaps in } \\
\text { knowledge and skills for } \\
\text { accurate data collection and } \\
\text { reporting and the } \\
\text { establishment of a quality } \\
\text { assurance mechanism for } \\
\text { elimination of FGM by 2017. } \\
\text { The policy describes a plan for } \\
\text { periodically monitoring sectoral } \\
\text { activities and intends for M\&E } \\
\text { activities to be implemented at } \\
\text { community, local government } \\
\text { area, state and national levels. } \\
\text { The National FGM Technical } \\
\text { Advisory Committee in } \\
\text { collaboration with National } \\
\text { Primary Health Care } \\
\text { Development Agency, Health } \\
\text { Planning and Research } \\
\text { Department of the FMOH, } \\
\text { National Bureau of Statistics } \\
\text { and NDHS Coordinator are } \\
\text { expected to collaborate to } \\
\text { develop indicators which } \\
\text { would be incorporated in the } \\
\text { NHMIS. The policy also tasks } \\
\text { the Federal Ministries of } \\
\text { Health, Women Affairs, Youth } \\
\text { Development, Education, } \\
\text { National Bureau of Statistics, } \\
\text { National Primary Healthcare } \\
\end{array}$ & $\begin{array}{l}\text { reports on activities nationally and } \\
\text { serve as the clearing house for the } \\
\text { collation and dissemination of } \\
\text { reports on the policy } \\
\text { implementation. Government } \\
\text { agencies and development partner } \\
\text { will submit quarterly reports to the } \\
\text { Reproductive Health Division. The } \\
\text { RH Division is also tasked with } \\
\text { developing necessary } \\
\text { mechanisms, tools, and guidelines } \\
\text { in relation the o the information } \\
\text { and data relevant for monitoring } \\
\text { the implementation process which } \\
\text { will include a National Framework } \\
\text { for M\&E of Reproductive Health } \\
\text { Programmes and Services and the } \\
\text { National Family Planning } \\
\text { Dashboard. A mid-term evaluative } \\
\text { will be undertaken in } 2019 \text {, midway } \\
\text { into policy implementation and } \\
\text { findings will be used to improve } \\
\text { programme planning and } \\
\text { implementation as well as the } \\
\text { development of future policies. }\end{array}$ \\
\hline
\end{tabular}




\begin{tabular}{|c|c|c|c|c|}
\hline $\begin{array}{l}\text { Components related to } \\
\text { prevention and } \\
\text { management of FGM/C }\end{array}$ & $\begin{array}{l}\text { National Gender Policy } \\
2006\end{array}$ & $\begin{array}{l}\text { National Policy on the } \\
\text { Health and Development } \\
\text { of Adolescents and } \\
\text { Young People } 2007\end{array}$ & $\begin{array}{l}\text { National Policy and Plan of } \\
\text { Action for the Elimination of } \\
\text { FGM in Nigeria 2013-2017 }\end{array}$ & $\begin{array}{l}\text { National Reproductive Health } \\
\text { Policy } 2017\end{array}$ \\
\hline & & & $\begin{array}{l}\text { Development Agency, National } \\
\text { Population Commission, } \\
\text { Research Institutions, and } \\
\text { Universities with generating } \\
\text { specific data to periodically } \\
\text { assess achievements in the } \\
\text { elimination of FGM/C with the } \\
\text { FMOH having overall } \\
\text { responsibility of compiling } \\
\text { reports of the activities of the } \\
\text { different sectors. Indicators for } \\
\text { assessing programme success } \\
\text { are mentioned in the policy } \\
\text { document and health-system } \\
\text { related indicators include: } \\
\text { - Development of a training } \\
\text { module on FGM } \\
\text { prevention and } \\
\text { management } \\
\text { - Number of hospitals and } \\
\text { clinics that provide } \\
\text { SRH/HIV and FGM } \\
\text { integration } \\
\text { - Associations with specific } \\
\text { penalty for medicalisation } \\
\text { of FGM } \\
\text { - Number of trainings held } \\
\text { for health care providers. }\end{array}$ & \\
\hline $\begin{array}{l}\text { Documentation of FGM/C } \\
\text { related data or cases }\end{array}$ & $\begin{array}{l}\text { There is no mention the } \\
\text { documentation of } F G M / C \\
\text { related data or cases. }\end{array}$ & $\begin{array}{l}\text { There is no mention of the } \\
\text { documentation of FGM/C } \\
\text { related data or cases by } \\
\text { the health sector, but the } \\
\text { policy notes that the health } \\
\text { sector has a responsibility }\end{array}$ & $\begin{array}{l}\text { Two of the policy targets are } \\
\text { the identification of appropriate } \\
\text { indicators and development } \\
\text { relevant data collection tools } \\
\text { on FGM elimination for } \\
\text { integration into the NHMIS and }\end{array}$ & $\begin{array}{l}\text { There is no mention of } \\
\text { documentation of FGM/C related } \\
\text { data or cases by the health sector } \\
\text { but the FMOH and State Ministries } \\
\text { of Health are tasked with } \\
\text { collecting, collating, and }\end{array}$ \\
\hline
\end{tabular}




\begin{tabular}{|c|c|c|c|c|}
\hline $\begin{array}{l}\text { Components related to } \\
\text { prevention and } \\
\text { management of FGM/C }\end{array}$ & $\begin{array}{l}\text { National Gender Policy } \\
2006\end{array}$ & $\begin{array}{l}\text { National Policy on the } \\
\text { Health and Development } \\
\text { of Adolescents and } \\
\text { Young People } 2007\end{array}$ & $\begin{array}{l}\text { National Policy and Plan of } \\
\text { Action for the Elimination of } \\
\text { FGM in Nigeria 2013-2017 }\end{array}$ & $\begin{array}{l}\text { National Reproductive Health } \\
\text { Policy } 2017\end{array}$ \\
\hline & & $\begin{array}{l}\text { to: develop national } \\
\text { research priorities on } \\
\text { young people's health and } \\
\text { development and } \\
\text { promote/support research } \\
\text { activities on such issues; } \\
\text { and to collect, collate and } \\
\text { disseminate relevant } \\
\text { national, state, and local } \\
\text { government area level } \\
\text { data about adolescent and } \\
\text { youth health services and } \\
\text { issues in a gender- } \\
\text { disaggregated form. }\end{array}$ & $\begin{array}{l}\text { the establishment of a system } \\
\text { for regular documentation, } \\
\text { dissemination and easy } \\
\text { access to information on FGM } \\
\text { by } 2017 \text {. The National FGM } \\
\text { Technical Advisory Committee } \\
\text { in collaboration with National } \\
\text { Primary Health Care } \\
\text { Development Agency, Health } \\
\text { Planning and Research } \\
\text { Department of the FMOH, } \\
\text { National Bureau of Statistics } \\
\text { and NDHS Coordinator are } \\
\text { expected to collaborate to } \\
\text { develop these indicators. }\end{array}$ & $\begin{array}{l}\text { disseminating national and state } \\
\text { information and data on } \\
\text { reproductive health status and } \\
\text { issues. }\end{array}$ \\
\hline
\end{tabular}


Table A5. Components relevant to health sector response to prevention and management of FGM/C in the Kenyan plans of actions

\begin{tabular}{|c|c|c|}
\hline $\begin{array}{l}\text { Components related to } \\
\text { prevention and } \\
\text { management of FGM/C }\end{array}$ & $\begin{array}{l}\text { National Plan of Action for the Elimination of FGM in } \\
\text { Kenya 1999-2019 }\end{array}$ & National Plan of Action for Children in Kenya 2015-2022 \\
\hline $\begin{array}{l}\text { Defines and classifies } \\
\text { FGM/C according to } \\
\text { WHO criteria }\end{array}$ & $\begin{array}{l}\text { Definition is consistent with WHO's definition } \\
\text { Classifies FGM/C into: clitoridectomy, excision and } \\
\text { infibulation. }\end{array}$ & $\begin{array}{l}\text { Definition is consistent with WHO's definition } \\
\text { No classification provided. }\end{array}$ \\
\hline $\begin{array}{l}\text { FGM/C-related health } \\
\text { and human rights } \\
\text { consequences were } \\
\text { outlined }\end{array}$ & $\begin{array}{l}\text { Highlights the health consequences of FGM/C namely; } \\
\text { immediate physical, gynaecological, sexual, psychological } \\
\text { complications }\end{array}$ & $\begin{array}{l}\text { Notes that FGM/C poses risks to the health and the lives of girls as well as } \\
\text { violates human rights. }\end{array}$ \\
\hline $\begin{array}{l}\text { Outlines factors } \\
\text { associated with FGM/C }\end{array}$ & $\begin{array}{l}\text { Highlights the social and cultural reasons underpinning } \\
\text { FGM/C }\end{array}$ & Not mentioned \\
\hline $\begin{array}{l}\text { Anchored on existing } \\
\text { legal and policy } \\
\text { frameworks }\end{array}$ & $\begin{array}{l}\text { States that there was no government policy and legislation } \\
\text { on FGM/C, but asserts that Kenya is signatory to many } \\
\text { international instruments for the eradication of FGM/C }\end{array}$ & $\begin{array}{l}\text { - The plan was organised according to the four pillars of the United } \\
\text { Nations Conventions on the Rights of the Child namely; survival, } \\
\text { development, protection and participation. } \\
\text { The first four chapters highlights the overall situation/status for each } \\
\text { pillar, the legal and policy framework as well as the planned } \\
\text { activities to achieve relevant targets for the period } 2015-2022 \text {. } \\
\text { The plan was aligned to the Constitution of Kenya 2010, is } \\
\text { designed to contribute to the realisation of the goals of Kenya } \\
\text { Vision 2030, and takes into consideration the SDGs. } \\
\text { The plan is informed by the Children Act, } 2001 \text { and the } \\
\text { recommendations of the African Charter on the Rights and Welfare } \\
\text { of the Child and the Prohibition of Female Genital Mutilation Act, } \\
2011 .\end{array}$ \\
\hline $\begin{array}{l}\text { Have a goal that is } \\
\text { consistent with the } \\
\text { theme of addressing } \\
\text { FGM/C }\end{array}$ & $\begin{array}{l}\text { To accelerate the elimination of FGM in order to improve } \\
\text { the health, quality of life and wellbeing of women, girls, } \\
\text { families and communities in Kenya }\end{array}$ & $\begin{array}{l}\text { To promote and protect the rights of children in Kenya, to assist and } \\
\text { continue to strengthen efforts to establish a mechanism for coordination } \\
\text { throughout the country and, trigger further allocation of adequate resources } \\
\text { to support children's rights at both national and local levels }\end{array}$ \\
\hline $\begin{array}{l}\text { Have objectives that are } \\
\text { consistent with the } \\
\text { theme of addressing } \\
\text { FGM/C }\end{array}$ & $\begin{array}{l}\text { The objectives include: } \\
\text { - } \quad \text { Reduce the proportion and prevalence of girls and } \\
\text { women undergoing any type of FGM/C; } \\
\text { - Increase the proportion of communities supporting } \\
\text { elimination of FGM/C through positive change in } \\
\text { attitude, beliefs, behaviour and practices; }\end{array}$ & $\begin{array}{l}\text { - The Plan provides an operational framework to guide stakeholders and } \\
\text { partners in implementing and monitoring programmes for the child. } \\
\text { - It outlines priorities and interventions necessary for the progressive } \\
\text { realisation of children's rights in Kenya. } \\
\text { - These priorities and interventions are designed to address the specific } \\
\text { gaps identified by stakeholders }\end{array}$ \\
\hline
\end{tabular}




\begin{tabular}{|c|c|c|}
\hline $\begin{array}{l}\text { Components related to } \\
\text { prevention and }\end{array}$ & $\begin{array}{l}\text { National Plan of Action for the Elimination of FGM in } \\
\text { Kenya 1999-2019 }\end{array}$ & National Plan of Action for Children in Kenya 2015-2022 \\
\hline & $\begin{array}{l}\text { - Increase the proportion health facilities at all levels } \\
\text { that provide care, counselling and support to girls/ } \\
\text { women with FGM/C-related physical and } \\
\text { psychological problems; } \\
\text { Increase the technical and advocacy of institutions, } \\
\text { agencies, communities in development, } \\
\text { implementation and management of FGM/C and } \\
\text { elimination programmes }\end{array}$ & \\
\hline $\begin{array}{l}\text { Have strategies to } \\
\text { achieve the objectives. }\end{array}$ & 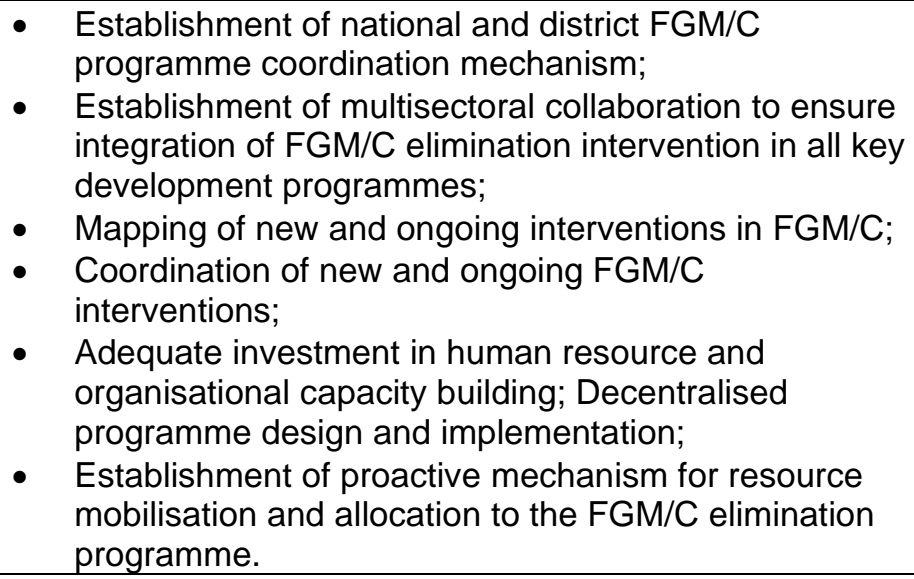 & $\begin{array}{l}\text { - Strengthen inter-sectoral coordination in child protection issues for the } \\
\text { juvenile justice system (police, probation, prison, judiciary and the } \\
\text { Children's Department) education, health and social system; } \\
\text { - Reinforce implementation of the FGM act and other legal provisions } \\
\text { fighting violence against children through negative beliefs and } \\
\text { practices. }\end{array}$ \\
\hline $\begin{array}{l}\text { Have an operational } \\
\text { framework }\end{array}$ & Not given & $\begin{array}{l}\text { - The Plan provides an operational framework to guide stakeholders } \\
\text { and partners in coordinating, planning, implementing and } \\
\text { monitoring programmes for the child. } \\
\text { - In addition, it outlines priorities and interventions necessary for the } \\
\text { progressive realisation of children's rights in Kenya. } \\
\text { - These priorities and interventions are designed to address the } \\
\text { specific gaps. }\end{array}$ \\
\hline $\begin{array}{l}\text { Provides a situation } \\
\text { analysis of } \mathrm{FGM} / \mathrm{C}\end{array}$ & $\begin{array}{l}\text { The magnitude and prevalence of FGM/C in Kenya is } \\
\text { provided }\end{array}$ & $\begin{array}{l}\text { - Highlights previous National Plan of Action } 2008-2012 \text { and } \\
\text { indicates that the Constitution and specific legislation had } \\
\text { strengthened the framework for child protection in several areas, } \\
\text { including FGM/C but the risk was still high. } \\
\text { - FGM/C prevalence is provided }\end{array}$ \\
\hline
\end{tabular}




\begin{tabular}{|c|c|c|}
\hline $\begin{array}{l}\text { Components related to } \\
\text { prevention and } \\
\text { management of FGM/C }\end{array}$ & $\begin{array}{l}\text { National Plan of Action for the Elimination of FGM in } \\
\text { Kenya 1999-2019 }\end{array}$ & National Plan of Action for Children in Kenya 2015-2022 \\
\hline M\&E & $\begin{array}{l}\text { Targets are set including: } \\
\text { - } \quad \text { Reduce by } 40 \text { percent the proportion of girls and } \\
\text { women undergoing FGM/C by the year 2019; } \\
\text { Increase the number of communities openly } \\
\text { discussing FGM/C; } \\
\text { - Increase management interventions for women } \\
\text { with FGM/C at community, district and national to } \\
\text { include psychosocial, medical and referral; } \\
\text { - Increase budget allocation from government and } \\
\text { NGOs on FGM/C; } \\
\text { FGM/C monitoring indicators developed and } \\
\text { incorporated in the national and district } \\
\text { development plans. }\end{array}$ & $\begin{array}{l}\text { No targets given but broad strategy statements } \\
\text { - Scale up child protection programmes, } \\
\text { - Strengthen the legal and policy framework including improved } \\
\text { coordination, } \\
\text { - } \quad \text { improve the financial, technical and professional capacity for duty } \\
\text { bearers, } \\
\text { - } \quad \text { creating awareness on various child protection issues, } \\
\text { Strengthen research for child protection. }\end{array}$ \\
\hline
\end{tabular}


Table A6. Components relevant to health sector response to prevention and management of FGM/C in Nigerian plans of actions and strategic frameworks

\begin{tabular}{|c|c|c|c|}
\hline $\begin{array}{l}\text { Components related to } \\
\text { prevention and } \\
\text { management of FGM/C }\end{array}$ & $\begin{array}{l}\text { National Strategic Framework on the Health and } \\
\text { Development of Adolescents and Young People in } \\
\text { Nigeria } 2007-2011\end{array}$ & $\begin{array}{l}\text { National Gender Policy } \\
\text { Strategic Framework } \\
\text { (Implementation Plan) } \\
2008 \text {-2013 }\end{array}$ & $\begin{array}{l}\text { National Policy and Plan of } \\
\text { Action for the Elimination of } \\
\text { Female Genital Mutilation in } \\
\text { Nigeria (2013 -2017) }\end{array}$ \\
\hline $\begin{array}{l}\text { Definition and classification of } \\
\text { FGM/C }\end{array}$ & Not defined. & Not defined. & \multirow{5}{*}{$\begin{array}{l}\text { Described under the policy } \\
\text { section of the document. See } \\
\text { Table A4 above. }\end{array}$} \\
\hline $\begin{array}{l}\text { Situational analysis of FGM/C } \\
\text { is provided }\end{array}$ & $\begin{array}{l}\text { It does not provide a situation analysis of FGM/C. The only } \\
\text { direct mention of FGM/C is in the situation analysis of the } \\
\text { SRH thematic area, where FGM/C is described as one of } \\
\text { the major forms of sexual and reproductive rights violations } \\
\text { affecting young people and as a harmful social practice that } \\
\text { affects their health and development. }\end{array}$ & Not provided. & \\
\hline $\begin{array}{l}\text { FGM/C-related health and } \\
\text { human rights consequences } \\
\text { are outlined }\end{array}$ & $\begin{array}{l}\text { The strategic framework recognises the rights and health } \\
\text { consequences of FGM/C but does not discuss them in } \\
\text { detail. }\end{array}$ & Not provided. & \\
\hline $\begin{array}{l}\text { Factors associated with } \\
\text { FGM/C are outlined }\end{array}$ & Not described. & Not described. & \\
\hline $\begin{array}{l}\text { Underlying legal and policy } \\
\text { framework }\end{array}$ & $\begin{array}{l}\text { The strategic framework does not specifically highlight its } \\
\text { underlying legal and policy framework concerning FGM/C, } \\
\text { but it does situate itself with reference to several frameworks } \\
\text { relevant to FGM/C including the following: National } \\
\text { Adolescent Health Policy } 1995 \text { and National Adolescent } \\
\text { Reproductive Health Strategic Framework 1999, the revised } \\
\text { National Health Policy, and the Millennium Development } \\
\text { Goals. }\end{array}$ & $\begin{array}{l}\text { The strategic framework } \\
\text { does not highlight laws and } \\
\text { policies relevant to FGM/C } \\
\text { but aligns itself with the } \\
\text { National Gender Policy, the } \\
\text { Constitution of the Federal } \\
\text { Republic of Nigeria and the } \\
\text { following international } \\
\text { human rights instruments - } \\
\text { the CEDAW, Protocol to the } \\
\text { African Charter on Human } \\
\text { and Peoples' Rights on the } \\
\text { Rights of Women in Africa, } \\
\text { the AU Solemn Declaration } \\
\text { on Gender Equality etc. }\end{array}$ & \\
\hline Goal & $\begin{array}{l}\text { The goal of the strategic framework is to facilitate the } \\
\text { implementation of the National Adolescent Health Policy that }\end{array}$ & $\begin{array}{l}\text { The strategic framework } \\
\text { (Implementation Plan) of }\end{array}$ & $\begin{array}{l}\text { Overall policy goal has been } \\
\text { described in the policy section }\end{array}$ \\
\hline
\end{tabular}




\begin{tabular}{|c|c|c|c|}
\hline $\begin{array}{l}\text { Components related to } \\
\text { prevention and } \\
\text { management of FGM/C }\end{array}$ & $\begin{array}{l}\text { National Strategic Framework on the Health and } \\
\text { Development of Adolescents and Young People in } \\
\text { Nigeria } 2007-2011\end{array}$ & $\begin{array}{l}\text { National Gender Policy } \\
\text { Strategic Framework } \\
\text { (Implementation Plan) } \\
2008-2013\end{array}$ & $\begin{array}{l}\text { National Policy and Plan of } \\
\text { Action for the Elimination of } \\
\text { Female Genital Mutilation in } \\
\text { Nigeria (2013 -2017) }\end{array}$ \\
\hline & $\begin{array}{l}\text { aims to improve the quality of life of young persons in } \\
\text { Nigeria. In addition to the other thematic areas ( } \mathrm{SRH} \text {, } \\
\text { nutrition, accidents, drug abuse, education, career and } \\
\text { employment, and parental responsibilities and social } \\
\text { adjustment) already addressed by the previous strategic } \\
\text { framework this new strategic framework aims to capture all } \\
\text { the domains of adolescent health (including adolescent } \\
\text { mental health, spirituality and rights for purpose of } \\
\text { completeness) that the national policy focuses on. }\end{array}$ & $\begin{array}{l}\text { the National Gender Policy } \\
\text { was developed from } \\
\text { priorities within the National } \\
\text { Gender Policy and seeks to } \\
\text { implement the core } \\
\text { principles and strategies of } \\
\text { the Gender Policy. }\end{array}$ & $\begin{array}{l}\text { the document. See Table A4 } \\
\text { above. The plan of action targets } \\
\text { the time period from } 2013-2017 \\
\text { and has four distinct sections in } \\
\text { line with the National FGM Policy } \\
\text { Framework: } \\
\text { - } \quad \text { plan of action for the } \\
\text { reduction of incidence and } \\
\text { prevalence of FGM/C in } \\
\text { Nigeria; } \\
\text { plan of action for the } \\
\text { promotion of behaviour } \\
\text { change initiatives towards the } \\
\text { elimination of FGM/C in } \\
\text { Nigeria; } \\
\text { plan of action for } \\
\text { strengthening the legal } \\
\text { framework for the elimination } \\
\text { of FGM/C at national and } \\
\text { state levels; } \\
\text { plan of action for the } \\
\text { strengthening of systems for } \\
\text { research, monitoring, and } \\
\text { evaluation towards the } \\
\text { elimination of FGM/C in } \\
\text { Nigeria }\end{array}$ \\
\hline Objectives & $\begin{array}{l}\text { Unlike the policy, which has a target to eliminate the } \\
\text { incidence of FGM/C, the strategic framework has no } \\
\text { objectives or indicators that speak directly to the prevention } \\
\text { and/or management of FGM/C. Instead there are several } \\
\text { objectives within the SRH thematic area within which } \\
\text { FGM/C prevention and management could be } \\
\text { mainstreamed. These objectives are the following: }\end{array}$ & $\begin{array}{l}\text { The strategic framework } \\
\text { does not have objectives } \\
\text { specific to FGM/C but } \\
\text { highlights the following } \\
\text { areas of focus where } \\
\text { FGM/C could be } \\
\text { mainstreamed: }\end{array}$ & $\begin{array}{l}\text { Described in the policy section of } \\
\text { the document. See Table } 5 .\end{array}$ \\
\hline
\end{tabular}




\begin{tabular}{|c|c|c|c|}
\hline $\begin{array}{l}\text { Components related to } \\
\text { prevention and } \\
\text { management of FGM/C }\end{array}$ & $\begin{array}{l}\text { National Strategic Framework on the Health and } \\
\text { Development of Adolescents and Young People in } \\
\text { Nigeria } 2007-2011\end{array}$ & $\begin{array}{l}\text { National Gender Policy } \\
\text { Strategic Framework } \\
\text { (Implementation Plan) } \\
2008 \text {-2013 }\end{array}$ & $\begin{array}{l}\text { National Policy and Plan of } \\
\text { Action for the Elimination of } \\
\text { Female Genital Mutilation in } \\
\text { Nigeria (2013 -2017) }\end{array}$ \\
\hline & $\begin{array}{l}\text { - To promote awareness of reproductive health issues of } \\
\text { young people amongst all stakeholders } \\
\text { - } \quad \text { To educate young people on SRH } \\
\text { including life skills training into existing family life and } \\
\text { HIV/AIDS education programmes in all schools } \\
\text { To build the capacity of stakeholders as advocates on } \\
\text { young people's reproductive health issues } \\
\text { To build the capacity of health workers and other } \\
\text { relevant groups in delivering quality reproductive health } \\
\text { information, counselling, and clinical services as well as } \\
\text { other development-oriented outputs for young people } \\
\text { Documentation and utilisation of FGM/C related data could } \\
\text { also be integrated into the following objectives: } \\
\text { - To strengthen the management information system for } \\
\text { effective M\&E of young people's reproductive health } \\
\text { activities } \\
\text { To strengthen the capacity of programme managers, } \\
\text { other relevant individuals and institutions at all levels to } \\
\text { conduct research activities on young people's } \\
\text { reproductive health issues } \\
\text { To enhance the capacity of programme managers at all } \\
\text { levels to utilise research findings and management } \\
\text { information system outputs in improving young people's } \\
\text { reproductive health programme management }\end{array}$ & $\begin{array}{l}\text { Establishment of an } \\
\text { institutional framework } \\
\text { for the advancement of } \\
\text { the status of women, } \\
\text { and the achievement of } \\
\text { gender equality; } \\
\text { Advocacy for the } \\
\text { promotion of new } \\
\text { attitudes, values and } \\
\text { behavior and a culture } \\
\text { of respect for all human } \\
\text { beings; } \\
\text { Strengthening the voice } \\
\text { and leadership of } \\
\text { women for continuous } \\
\text { organising, advocacy } \\
\text { and ensuring that } \\
\text { gender equality issues } \\
\text { remain high on the } \\
\text { national agenda }\end{array}$ & \\
\hline $\begin{array}{l}\text { Strategies and activities for } \\
\text { health system related } \\
\text { targets }\end{array}$ & $\begin{array}{l}\text { Does not contain any FGM/C specific strategies, activities or } \\
\text { targets }\end{array}$ & $\begin{array}{l}\text { It contains a reference to } \\
\text { FGM/C (not health sector } \\
\text { related) in an output (under } \\
\text { Outcome 2) which states } \\
\text { that harmful traditional } \\
\text { practices against women } \\
\text { are criminalised in Nigeria }\end{array}$ & $\begin{array}{l}\text { Objective } 1.2 \\
\text { Strategies \& Activities: } \\
\text { - Capacity building for } \\
\text { prevention and management } \\
\text { of FGM complications } \\
\text { through: }\end{array}$ \\
\hline
\end{tabular}




\begin{tabular}{|c|c|c|c|}
\hline $\begin{array}{l}\text { Components related to } \\
\text { prevention and } \\
\text { management of FGM/C }\end{array}$ & $\begin{array}{l}\text { National Strategic Framework on the Health and } \\
\text { Development of Adolescents and Young People in } \\
\text { Nigeria } 2007-2011\end{array}$ & $\begin{array}{l}\text { National Gender Policy } \\
\text { Strategic Framework } \\
\text { (Implementation Plan) } \\
2008-2013\end{array}$ & $\begin{array}{l}\text { National Policy and Plan of } \\
\text { Action for the Elimination of } \\
\text { Female Genital Mutilation in } \\
\text { Nigeria }(2013-2017)\end{array}$ \\
\hline & & $\begin{array}{l}\text { and the indicator of success } \\
\text { for this output is the number } \\
\text { of states with legislation } \\
\text { against harmful traditional } \\
\text { practices (widowhood } \\
\text { practices, child marriages, } \\
\text { FGM/C). Strategic } \\
\text { interventions to achieve this } \\
\text { output include: } \\
\text { - Analysis of all existing } \\
\text { harmful practices } \\
\text { across the country. } \\
\text { - Development of Bills to } \\
\text { abolish the practices by } \\
\text { the States } \\
\text { - Advocacy with Houses' } \\
\text { of Assemblies and } \\
\text { submission of Bills } \\
\text { The framework contains a } \\
\text { health sector related output } \\
\text { under the same outcome in } \\
\text { which FGM/C issues could } \\
\text { be mainstreamed. This } \\
\text { output is the existence of a } \\
\text { national response on SGBV } \\
\text { and women rights abuses. } \\
\text { Strategic interventions } \\
\text { include: } \\
\text { Development of } \\
\text { national guidelines on } \\
\text { SGBV }\end{array}$ & $\begin{array}{l}\text { Develop training modules } \\
\text { on prevention and } \\
\text { management of FGM/C } \\
\text { Training of trainers on } \\
\text { FGM/C Training Module } \\
\text { Production and } \\
\text { distribution of FGM/C } \\
\text { training modules } \\
\text { Sensitisation workshop } \\
\text { on dangers of FGM/C } \\
\text { - Service delivery through: } \\
\text { Integrating FGM/C into } \\
\text { SRH/HIV services } \\
\text { - Advocacy to training } \\
\text { institutions for health care } \\
\text { providers to integrate FGM/C } \\
\text { module into their training } \\
\text { curricula } \\
\text { Objective } 1.3 \text { Strategies \& } \\
\text { Activities } \\
\text { Sensitisation of regulatory } \\
\text { bodies and professional } \\
\text { associations for health care } \\
\text { providers on medicalisation of } \\
\text { FGM/C } \\
\text { M\&E support to regulatory } \\
\text { authorities to monitor FGM/C } \\
\text { practices in the health sector } \\
\text { Behaviour change } \\
\text { communications material } \\
\text { development including: } \\
\text { Advocacy kits targeted at } \\
\text { State commissioners of }\end{array}$ \\
\hline
\end{tabular}




\begin{tabular}{|c|c|c|c|}
\hline $\begin{array}{l}\text { Components related to } \\
\text { prevention and } \\
\text { management of FGM/C }\end{array}$ & $\begin{array}{l}\text { National Strategic Framework on the Health and } \\
\text { Development of Adolescents and Young People in } \\
\text { Nigeria } 2007-2011\end{array}$ & $\begin{array}{l}\text { National Gender Policy } \\
\text { Strategic Framework } \\
\text { (Implementation Plan) } \\
2008-2013\end{array}$ & $\begin{array}{l}\text { National Policy and Plan of } \\
\text { Action for the Elimination of } \\
\text { Female Genital Mutilation in } \\
\text { Nigeria (2013 -2017) }\end{array}$ \\
\hline & & 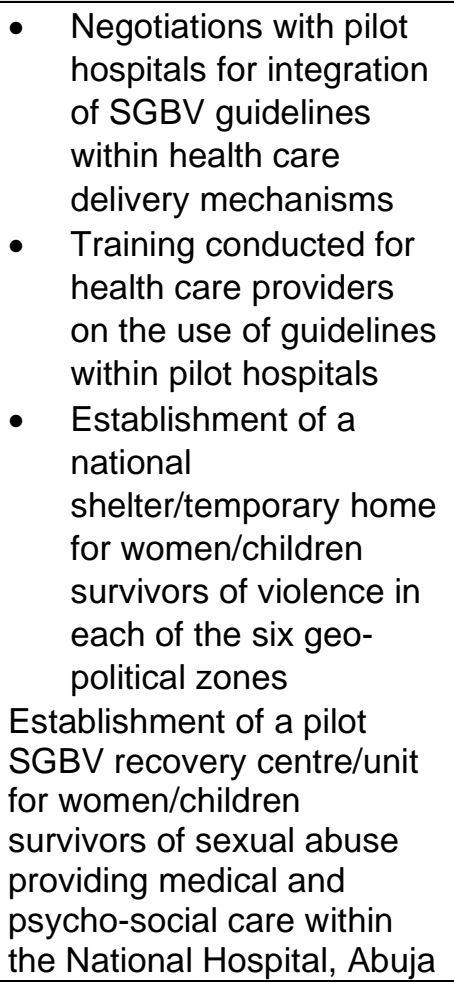 & $\begin{array}{l}\text { health, health } \\
\text { professional associations } \\
\text { Training modules for } \\
\text { health workers } \\
\text { Job aids for health } \\
\text { workers } \\
\text { Posters, flyers, leaflets, } \\
\text { etc }\end{array}$ \\
\hline Research, M\&E & $\begin{array}{l}\text { The FMOH is expected to collaborate with all partners for } \\
\text { the successful and effective implementation of the } \\
\text { framework. The strategy has indicators under each of its } \\
\text { thematic area with which programmes can be monitored and } \\
\text { evaluated. Government agencies are expected to monitor } \\
\text { activities in the sector within their mandate, and according to } \\
\text { the appropriate tier of government. The document states } \\
\text { that a comprehensive evaluation of the implementation of } \\
\text { the framework would be undertaken nationally every five }\end{array}$ & $\begin{array}{l}\text { The framework delineates } \\
\text { expected outcomes, } \\
\text { outputs, indicators, } \\
\text { responsible agencies, and } \\
\text { strategic interventions. The } \\
\text { Gender Management } \\
\text { System is the coordination } \\
\text { mechanism for managing } \\
\text { and implementing the }\end{array}$ & $\begin{array}{l}\text { The plan of action describes the } \\
\text { following objectives, strategies, } \\
\text { and activities to strengthen } \\
\text { systems for research, M\&E } \\
\text { towards the elimination of FGM: } \\
\text { Objective } 4.1 \text { : To strengthen } \\
\text { intersectoral collaboration for } \\
\text { M\&E for FGM elimination in } \\
\text { Nigeria by } 2017\end{array}$ \\
\hline
\end{tabular}




\begin{tabular}{|c|c|c|c|}
\hline $\begin{array}{l}\text { Components related to } \\
\text { prevention and } \\
\text { management of FGM/C }\end{array}$ & $\begin{array}{l}\text { National Strategic Framework on the Health and } \\
\text { Development of Adolescents and Young People in } \\
\text { Nigeria } 2007-2011\end{array}$ & $\begin{array}{l}\text { National Gender Policy } \\
\text { Strategic Framework } \\
\text { (Implementation Plan) } \\
2008-2013\end{array}$ & $\begin{array}{l}\text { National Policy and Plan of } \\
\text { Action for the Elimination of } \\
\text { Female Genital Mutilation in } \\
\text { Nigeria (2013 -2017) }\end{array}$ \\
\hline & $\begin{array}{l}\text { years and that results of M\&E activities would be used to } \\
\text { improve programme planning and implementation as well as } \\
\text { the development of future frameworks. }\end{array}$ & $\begin{array}{l}\text { National Gender Policy and } \\
\text { is coordinated by the } \\
\text { Gender Management } \\
\text { Structure, which is led by } \\
\text { the Federal Ministry of } \\
\text { Women Affairs. }\end{array}$ & $\begin{array}{l}\text { Strategies \& activities } \\
\text { - } \quad \text { Advocacy through visits to } \\
\text { stakeholders on FGM/C to } \\
\text { support M\&E and research } \\
\text { efforts } \\
\text { Objective 4.2: To define/identify } \\
\text { indicators and develop } \\
\text { appropriate data collection tools } \\
\text { for monitoring FGM/C elimination } \\
\text { efforts by } 2015 \\
\text { Strategies \& activities } \\
\text { Organising a workshop to } \\
\text { define, identify \& develop } \\
\text { indicators/data collection } \\
\text { tools } \\
\text { Objective 4.3: To strengthen } \\
\text { national capacity for M\&E of FGM } \\
\text { elimination in Nigeria by } 2015 \\
\text { Strategies \& activities } \\
\text { Capacity building through } \\
\text { trainings for M\&E personnel } \\
\text { from all FGM/C stakeholders } \\
\text { to address capacity gaps for } \\
\text { utilising data capturing tools } \\
\text { Objective 4.4: To establish quality } \\
\text { assurance mechanism for FGM/C } \\
\text { elimination by } 2017 \\
\text { Strategies \& activities } \\
\text { M\&E through } \\
\text { O Periodic monitoring visits } \\
\text { to FGM/C intervention } \\
\text { sites }\end{array}$ \\
\hline
\end{tabular}




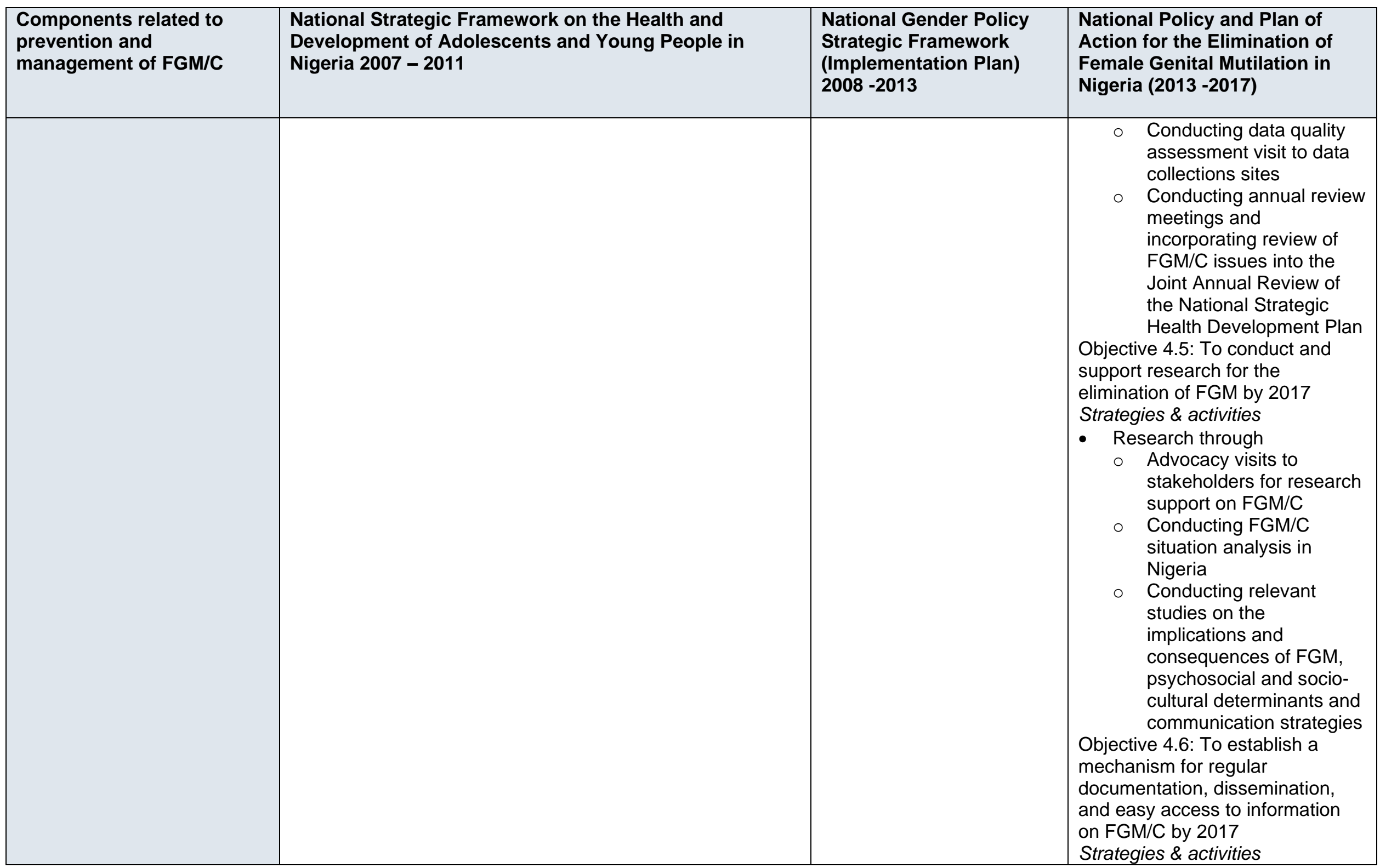




\begin{tabular}{|c|c|c|c|}
\hline $\begin{array}{l}\text { Components related to } \\
\text { prevention and } \\
\text { management of FGM/C }\end{array}$ & $\begin{array}{l}\text { National Strategic Framework on the Health and } \\
\text { Development of Adolescents and Young People in } \\
\text { Nigeria } 2007-2011\end{array}$ & $\begin{array}{l}\text { National Gender Policy } \\
\text { Strategic Framework } \\
\text { (Implementation Plan) } \\
2008-2013\end{array}$ & $\begin{array}{l}\text { National Policy and Plan of } \\
\text { Action for the Elimination of } \\
\text { Female Genital Mutilation in } \\
\text { Nigeria }(2013-2017)\end{array}$ \\
\hline & & & $\begin{array}{l}\text { Documentation and } \\
\text { information sharing through } \\
\text { Creating a web-based } \\
\text { information system for } \\
\text { FGM/C information in } \\
\text { Nigeria } \\
\text { Producing and } \\
\text { disseminating FGM/C } \\
\text { publications, research, } \\
\text { intervention reports using } \\
\text { developed website and } \\
\text { FGM/C day } \\
\text { commemoration } \\
\text { Setting up documentation } \\
\text { centres in strategic points } \\
\text { nationally to provide easy } \\
\text { access to resource }\end{array}$ \\
\hline Costed Activities & Activities are not costed. & $\begin{array}{l}\text { The framework contains a } \\
\text { five-year indicative budget } \\
\text { for its activities. }\end{array}$ & $\begin{array}{l}\text { Every activity listed in the plan of } \\
\text { action has been costed and } \\
\text { recommended institutions to } \\
\text { obtain funding from are listed. } \\
\text { Recommended sources for the } \\
\text { funding are also provided. For } \\
\text { some activities, specific } \\
\text { institutions like the FMOH are } \\
\text { listed but in other cases the } \\
\text { suggestions are less specific for } \\
\text { example "government" and } \\
\text { "development partners." }\end{array}$ \\
\hline
\end{tabular}


Table A7a. Components relevant to prevention and management of FGM/C in the Kenyan national school health guidelines

\begin{tabular}{|l|l|}
\hline $\begin{array}{l}\text { Components related to prevention and } \\
\text { management of FGM/C }\end{array}$ & Kenya National School Health Guidelines \\
\hline $\begin{array}{l}\text { The guideline is aimed at directing } \\
\text { coordinated implementation of quality } \\
\text { health interventions in Kenyan basic }\end{array}$ & $\begin{array}{l}\text { Provides guidance, practical coordination and engagement by the MoH and MoE, and other relevant } \\
\text { stakeholders to enhance coordination in the planning, designing and implementation of sustainable quality } \\
\text { health interventions in basic education levels in Kenya. }\end{array}$
\end{tabular}

health interventions in Kenyan qasic

education levels

Structure and utility of the guideline is outlined

- The guidelines states per thematic areas, the objective, policy statement(s) and strategies as they are highlighted in the main policy document.

- Each strategy broadly identifies key activities and processes that will lead to its realisation.

- For accountability, the guidelines identify and list down those responsible for implementation of the specific activities and driving the processes.

- It provide key policy, legal and guidelines in Kenya that the school health policy is being anchored to complement efforts in Kenya in enhancing good health for basic education.

Objective addressing FGM/C is found in the theme of gender, growth and development

Policy statement reiterate collaboration with stakeholders as important in addressing FGM

Strategies for addressing FGM/C include protection and response to girls exposed to $\mathrm{FGM} / \mathrm{C}$

Guidelines on prevention and management of GBV and FGM/C interventions including counselling are highlighted.
Help learners transcend gender dynamics and safeguard them from all forms of gender based violence and harmful cultural practices that may affect enjoyment of their rights (right to life and survival, development, protection, and participation).

Ministry of Education in collaboration with Ministry of Health, other line ministries and departments, and other stakeholders shall address gender related issues which affect education, health and wellbeing of learners

- Enhance the safeguards against gender based violence amongst learners

- Safeguards and protect the learners from harmful cultural practices

- Provide psychosocial counselling, screening and other health services to learners

Promote awareness among learners and other school community members on forms of GBV and existing legal and policy frameworks for GBV;

- Strengthen the prevention and response to GBV by provision of medical, legal and psychosocial support for survivors

- Support survivors of gender based violence by referring them to the nearest health facility.

- Sensitise learners and members of school community on the negative effects of these practices

- Strengthen collaboration with relevant stakeholders to enhance access, linkages and referrals to psychosocial, medical and legal support services

- Promote school re-entry by learners who have dropped out of school or rescued from these practices, in line with the school re-entry guidelines

- Ensure provision of low cost boarding schools and rescue centres for learners in vulnerable settings

- Establish and strengthen psychosocial counselling and other support services to all learners at all times with a designated teacher 


\begin{tabular}{|c|c|}
\hline Components related to prevention and & Kenya National School Health Guidelines \\
\hline & - $\quad$ Link school to a nearby health facility for psychosocial counselling and other health services \\
\hline $\begin{array}{l}\text { Actors across sectors responsible for } \\
\text { various FGM/C-related interventions are } \\
\text { listed }\end{array}$ & $\begin{array}{ll}\text { - } & \text { Ministry of health } \\
\text { - } & \text { Ministry of education } \\
\text { - } & \text { County Government } \\
\text { - } & \text { Ministry of public service, youth and gender } \\
\text { - } & \text { Ministry of Labour and special programs } \\
\text { - } & \text { Parents } \\
\text { - } & \text { Teachers } \\
\text { - } & \text { Community Learners } \\
\text { - } & \text { Board of Management } \\
\text { - } & \text { Religious leaders } \\
\text { - } & \text { Development partners } \\
\text { - Judiciary } \\
\text { - Teachers Service Commission } \\
\text { - Teacher Training Institutions }\end{array}$ \\
\hline $\begin{array}{l}\text { Objective addressing FGM/C is also } \\
\text { found in the theme of child rights and } \\
\text { responsibilities }\end{array}$ & $\begin{array}{l}\text { Inform learners and other members of the school community on their rights and responsibilities and ensure } \\
\text { they take up their responsibilities }\end{array}$ \\
\hline $\begin{array}{l}\text { Policy statement reiterate collaboration } \\
\text { with stakeholders as important in } \\
\text { prevention and response to FGM/C }\end{array}$ & $\begin{array}{l}\text { Ministry of Education in collaboration with other line ministries and stakeholders shall promote, safeguard and } \\
\text { protect the rights of the learners and ensure that they carry out their responsibilities. }\end{array}$ \\
\hline $\begin{array}{l}\text { Strategies for addressing FGM/C include } \\
\text { protection rights }\end{array}$ & Provide a conducive environment for the enjoyment of the protection rights by the learner \\
\hline $\begin{array}{l}\text { Guidelines addressing prevention and } \\
\text { management of GBV including FGM/C } \\
\text { interventions highlighted }\end{array}$ & $\begin{array}{l}\text { - Sensitisation on the legal and policy frameworks including coordination for child protection in all areas } \\
\text { - } \quad \text { Establish and strengthen institutional structures that provide child protection services and welfare in } \\
\text { schools } \\
\text { - } \quad \text { Provide psychosocial care and support to children who have gone through child abuse. } \\
\text { - } \quad \text { Encourage school to have a capacity build on child rights } \\
\text { - Support the provision of affordable, specialised medical care for the affected children }\end{array}$ \\
\hline $\begin{array}{l}\text { Multi sectoral actors are responsible for } \\
\text { various FGM/C-related interventions are } \\
\text { listed }\end{array}$ & $\begin{array}{ll}\text { - } & \text { Ministry of health } \\
\text { - } & \text { Ministry of education } \\
\text { - } & \text { County Government } \\
\text { - } & \text { Teachers Service Commission } \\
\text { - } & \text { Ministry of Labour and special programs } \\
\text { - } & \text { Teachers }\end{array}$ \\
\hline
\end{tabular}




\begin{tabular}{|c|c|}
\hline Components related to prevention and & Kenya National School Health Guidelines \\
\hline & $\begin{array}{ll}\text { - } & \text { Board of Management } \\
\text { - } & \text { Parents } \\
\text { - } & \text { Religious leaders } \\
\text { - } & \text { Kenya Institute of Curricula development } \\
\text { - } & \text { Development partners } \\
\text { - } & \text { Teacher training college } \\
\text { - Judiciary }\end{array}$ \\
\hline $\begin{array}{l}\text { Objective addressing FGM/C is also } \\
\text { found in the theme of cross cutting issues }\end{array}$ & Harmful gender related cultural practices shall be discouraged both in schools and in the community \\
\hline $\begin{array}{l}\text { Guideline provides for collaboration, } \\
\text { partnership, integration for sustainability } \\
\text { of school health policy }\end{array}$ & $\begin{array}{l}\text { Emphasis on planning, implementation, monitoring and evaluation for a sustainable comprehensive school } \\
\text { health program characterised by: } \\
\text { - Enhanced coordination of school health interventions by } \mathrm{MOH}, \mathrm{MOE} \text {, relevant ministries, non-state } \\
\text { - } \text { actors, learners and community members } \\
\text { - } \quad \text { Participation of all stakeholders including learners for sustainability at all stages } \\
\text { - Evidence based interventions } \\
\text { - Aligning the implementation to existing legal and policy frameworks related to school health in Kenya } \\
\quad \text { as well as ratified international conventions }\end{array}$ \\
\hline Guideline provides for capacity building & 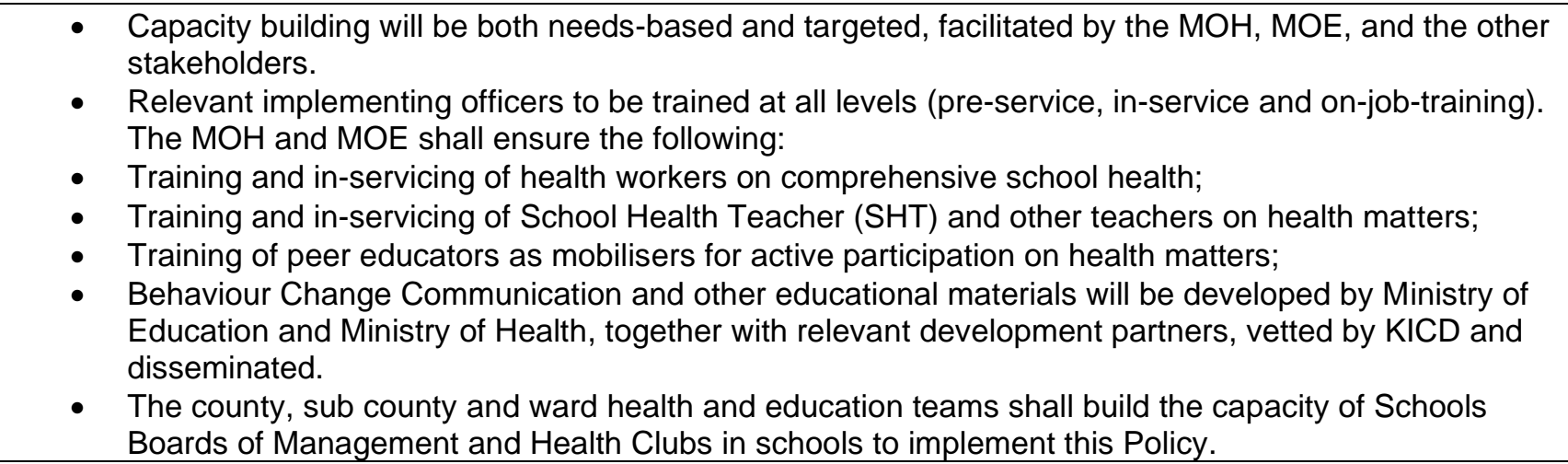 \\
\hline $\begin{array}{l}\text { Guideline provide for advocacy, } \\
\text { communication and social mobilisation }\end{array}$ & $\begin{array}{l}\text { - Local coordinating committees shall be involved in advocacy and mobilisation of county and sub } \\
\text { county resources. } \\
\text { - } \quad \text { Advocacy, Communication and social mobilisation for improved health shall be conducted at all levels } \\
\text { - } \quad \text { Resource Mobilisation and Allocation shall be conducted both locally and internationally. }\end{array}$ \\
\hline
\end{tabular}




\begin{tabular}{|c|c|}
\hline Components related to prevention and & Kenya National School Health Guidelines \\
\hline & $\begin{array}{l}\text { - Appropriate need based allocation shall be encouraged for the implementation which will be effective } \\
\text { and impactful to the health of the learners, school community and immediate neighbours of the school. }\end{array}$ \\
\hline $\begin{array}{l}\text { Guideline provide for supervision, } \\
\text { monitoring, evaluation and reporting. }\end{array}$ & $\begin{array}{l}\text { Monitoring } \\
\text { - County and Sub County School Health Teams are to lead in coordination and implementation of } \\
\text { school health programmes at their levels. } \\
\text { - Provide for establishment and development of a robust monitoring and evaluation system, specifying } \\
\text { mechanisms, tools and indicators to be monitored. } \\
\text { - The monitoring and evaluation system shall have inbuilt indicators that will facilitate such reviews and } \\
\text { evaluation. } \\
\text { Database } \\
\text { - The Ministries of Health and Education to use the data in the reports to create the database on school } \\
\text { health at all levels using cost-effective methodologies including Geographical Information Systems. } \\
\text { - Regular data updated to keep information accurate and relevant. } \\
\text { Partners implementing school health activities to avail any data to the Sub County School Health } \\
\text { Coordinators and copies to the County School Health Coordinators and National School Health } \\
\text { Secretariat respectively. }\end{array}$ \\
\hline Provision for reporting framework & Reports are to submitted biannually and annually as stipulated for the different committee \\
\hline Provision for research component & $\begin{array}{l}\text { - Address new and emerging issues on School health, at least a study will be commissioned annually } \\
\text { by the National School Health technical committee } \\
\text { - } \quad \text { Findings will be disseminated to stakeholders at National and county levels. }\end{array}$ \\
\hline Provision for implementation blueprint & $\begin{array}{l}\text { - Key school health recommendations have been provided with timelines (2030) for implementation as } \\
\text { well as the structures charged with responsibility. } \\
\text { - National School Health Secretariat with technical support from the National School Health Technical } \\
\text { Committee and National School Health Interagency Coordinating Committee are identified to lead } \\
\text { implementation. }\end{array}$ \\
\hline
\end{tabular}


Table A8b. Components relevant to prevention and management of FGM/C in the Kenyan reference manual for health service providers

\begin{tabular}{|c|c|}
\hline $\begin{array}{l}\text { Components related to prevention and } \\
\text { management of } \mathrm{FGM} / \mathrm{C}\end{array}$ & $\begin{array}{l}\text { Management of complications, pregnancy, childbirth and the postpartum period in the presence of } \\
\text { FGM/C. A Reference Manual for Health Service Providers }\end{array}$ \\
\hline $\begin{array}{l}\text { Objectives that address response to } \\
\text { prevention and Management of FGM/C } \\
\text { are highlighted }\end{array}$ & $\begin{array}{l}\text { - Define and classify FGM/C; } \\
\text { - } \text { Describe why different communities practice FGM/C, short- and long-term physical complications of } \\
\text { FGM/C, psychosocial and sexual complications of FGM/C, ethical implications of FGM/C } \\
\text { - Provide health workers with knowledge and skills in managing complications associated with FGM/C; } \\
\text { - Describe the ethical implications of FGM/C; } \\
\text { - Describe the laws and decrees against FGM/C and the legal implications. }\end{array}$ \\
\hline $\begin{array}{l}\text { Definition and classification of FGM/C is } \\
\text { as per the WHO criteria }\end{array}$ & $\begin{array}{l}\text { Defined FGM/C according to the WHO criteria } \\
\text { Classification of FGM/C is a per WHO typology }\end{array}$ \\
\hline $\begin{array}{l}\text { Provides highlights on the prevalence of } \\
\text { FGM/C in Kenya }\end{array}$ & Prevalence of FGM/C in Kenya as well as for specific ethnic groups is provided \\
\hline Provides reasons for performing FGM/C & The s \\
\hline Describes who performs FGM/C in Kenya & Highlights the role of traditional cutters in FGM/C \\
\hline Describes medicalisation of $\mathrm{FGM} / \mathrm{C}$ & Describes the role of health care providers/health facilities in perpetuating FGM/C \\
\hline $\begin{array}{l}\text { Provides a description of FGM/C-related } \\
\text { complications }\end{array}$ & $\begin{array}{l}\text { The manual addresses the following complications: Immediate physical complications due to the procedure; } \\
\text { long-term physical complications; gynaecological complications; obstetric complications associated with } \\
\text { FGM/C; potential complications with the foetus or baby; psychosocial consequences; sexual complications of } \\
\text { FGM/C; Complications associated with FGM/C that affect men. }\end{array}$ \\
\hline $\begin{array}{l}\text { Describes management interventions for } \\
\text { immediate and short-term complications } \\
\text { of } F G M / C\end{array}$ & $\begin{array}{l}\text { The manual provides management approaches for the following FGM/C-related complications: immediate } \\
\text { physical complications due to the procedure, long-term physical complications, gynaecological complications, } \\
\text { obstetric complications associated with FGM/C, potential complications with the foetus or baby, psychosocial } \\
\text { consequences, sexual complications of } F G M / C \text {, complications associated with } F G M / C \text { that affect men. }\end{array}$ \\
\hline $\begin{array}{l}\text { Describes the role of health care } \\
\text { providers in preventing } \mathrm{FGM} / \mathrm{C}\end{array}$ & $\begin{array}{l}\text { The manual elaborates on the role of health care providers in addressing response to prevention and } \\
\text { management of FGM/C. }\end{array}$ \\
\hline $\begin{array}{l}\text { Provides policy statements regarding the } \\
\text { prevention and management of } \mathrm{FGM} / \mathrm{C}\end{array}$ & $\begin{array}{l}\text { The following policy statements are highlighted in the manual as derived from WHO and international medical } \\
\text { bodies that strongly oppose FGM/C: Policy No. 1-Opening up of Type III FGM (infibulation); Policy No. 2- } \\
\text { Refusal of requests to re-stitch an opened-up vulva (re-infibulation); Policy No. 3-Performance of functions that } \\
\text { are outside the nurse's/midwife's legal scope of practice; Policy No. 4-Documentation of FGM/C; Policy No. 5- } \\
\text { Prevention of FGM/C by nurses, midwives, and other health care professionals }\end{array}$ \\
\hline $\begin{array}{l}\text { Highlights human rights impl } \\
\text { associated with FGM/C }\end{array}$ & $\begin{array}{l}\text { The manual highlights violation of human rights associated with } \mathrm{FGM} / \mathrm{C} \text { notably; the right to health, the right to } \\
\text { be free of cruel and degrading practices, the right to sexual and corporal integrity, and the right to }\end{array}$ \\
\hline
\end{tabular}


Table A9. Components relevant to prevention and management of FGM/C in Nigerian Health sector guidelines

\begin{tabular}{|c|c|}
\hline $\begin{array}{l}\text { Components related to prevention } \\
\text { and management of FGM/C }\end{array}$ & Standards and Guidelines for the Medical Management of Victims of Violence in Nigeria \\
\hline Objectives & $\begin{array}{l}\text { - Help health-care providers at all levels to incorporate messages/information about prevention and } \\
\text { management of gender and other forms of violence in all communications to stakeholders and the } \\
\text { communities; } \\
\text { - Provide health-care providers with the capacity to manage victims of gender and other forms of violence } \\
\text { including FGM/C, harmful widowhood practices and its consequences; } \\
\text { - Set standards for the medical management of victims of gender and other forms of violence, including FGM/C } \\
\text { and harmful widowhood practices; } \\
\text { Guide health-care policy makers and managers on how to incorporate gender and other forms of violence } \\
\text { when making policies, budgeting, training requirements, and equipping facilities. }\end{array}$ \\
\hline Definition and classification of FGM/C & Consistent with WHO definition. It also describes the WHO classification of FGM/C types. \\
\hline $\begin{array}{l}\text { Discusses prevalence of FGM/C in } \\
\text { Nigeria }\end{array}$ & Provided citing the 2013 NDHS \\
\hline $\begin{array}{l}\text { Discusses reasons for performing } \\
\text { FGM/C }\end{array}$ & $\begin{array}{l}\text { Provides information broadly but notes that reasons vary and include: attempts at curbing the sexual drive of } \\
\text { women to ensure virginity or prevent promiscuity, purification, family honour, hygiene and aesthetics, religion, } \\
\text { husband's sexual pleasure, rite of passage for girls, myths like prevention of perinatal mortality }\end{array}$ \\
\hline Discusses providers of FGM/C & Traditional birth attendants, healers and health workers. Notes that medicalisation is prohibited under the law. \\
\hline $\begin{array}{l}\text { Discusses FGM/C-related } \\
\text { complications }\end{array}$ & $\begin{array}{l}\text { The standards and guidelines mentions the following complications: haemorrhage, shock, sepsis, genital } \\
\text { abscesses, septicaemia, urinary retention, pains, injury, to adjacent tissues, failure to heal, pelvic peritonitis, } \\
\text { vesico-vaginal fistula, recto-vaginal fistula, acquired gynaetresia, lacerations and fractures from the victim } \\
\text { struggling during the procedure, scar tissue, keloids, dyspareunia, apareunia, vaginismus, frigidity, dysuria, } \\
\text { recurrent urinary tract infections, dysmenorrhea, haematocolpos, dystocia during delivery from soft tissue, } \\
\text { perinatal mortality, psychological problems like low self-esteem, fear, suppression of feelings, bitterness, anger, } \\
\text { feelings of betrayal. }\end{array}$ \\
\hline Managing complications FGM/C & $\begin{array}{l}\text { The standards and guidelines discuss management in very broad terms dividing this section into management in } \\
\text { early presentation and management in late presentation. The guidelines are not complication specific or detailed. } \\
\text { They are not adequate for effective management of FGM/C complications. } \\
\text { Management in early presentation involves the following: } \\
\text { - Taking a full history - patient's bio data, date and time of procedure, place procedure was done, who } \\
\text { performed the procedure, type and sterility of instruments used, anaesthesia given, quantity of blood loss, } \\
\text { loss of consciousness, fever, etc. } \\
\text { Do a comprehensive examination with emphasis on the external genitalia. Check vital signs, pallor, jaundice; } \\
\text { check perineum for cuts, pus, blood, type of circumcision, sutures, etc }\end{array}$ \\
\hline
\end{tabular}




\begin{tabular}{|c|c|}
\hline Components related to prevention & Standards and Guidelines for the Medical Management of Victims of Violence in Nigeria \\
\hline & $\begin{array}{l}\text { - Manage according to findings - treat sepsis/septicaemia (antibiotics, dressing/sitz bath, incision and } \\
\text { drainage), arrest bleeds, give analgesics and tetanus toxoid. Investigate for infection or anaemia. Give } \\
\text { haematinics and transfuse blood if necessary. } \\
\text { - } \quad \text { Give psychosocial counselling } \\
\text { - } \quad \text { Refer to appropriate medical discipline and/or other agencies who can meet the identified need. } \\
\text { Management in late presentation entails the following: } \\
\text { - } \quad \text { Full history and physical examination } \\
\text { - } \quad \text { Discuss the diagnosis and treatment options } \\
\text { - } \quad \text { May do de-infibulation or dilatation } \\
\text { - } \quad \text { Offer psychosocial counselling. }\end{array}$ \\
\hline $\begin{array}{l}\text { The role of health care providers in } \\
\text { preventing and managing } \mathrm{FGM} / \mathrm{C}\end{array}$ & $\begin{array}{l}\text { This is discussed briefly in the document. It mentions that some health workers are "ignorantly" performing the } \\
\text { practice and notes that this is illegal. It also emphasises that health workers should ask for consent to report } \\
\text { FGM/C to the police even though it is often difficult to obtain that consent from victims since perpetrators are } \\
\text { usually family members. Additionally, the guidelines explain that the } 2013-2017 \text { National Policy and Plan of } \\
\text { Action for the Elimination of Female Genital Mutilation expects health workers to improve their knowledge and } \\
\text { capacity to handle cases of FGM/C and provide education to communities. }\end{array}$ \\
\hline Describes national response to FGM/C & $\begin{array}{l}\text { The standards and guidelines mention the World Health Assembly Resolution of } 1994 \text { (resolution to eliminate } \\
\text { FGM/C) and describes the national response in Nigeria as having included the following: } \\
\text { baseline surveys and research to document the extent and impact (NDHS, National Baseline Survey, Best } \\
\text { practices); National Policy and Plan of Action on Female Genital Mutilation (2002 -2008, 2013 - 2017); legislation } \\
\text { in state and national assemblies (e.g. VAPP Act, 2015); community level education and awareness creation; and } \\
\text { collaboration with national and international agencies. }\end{array}$ \\
\hline Human rights implications of FGM/C & The standards and guidelines do not discuss the human rights implications of the practice. \\
\hline
\end{tabular}

